\title{
Expedition 301 summary ${ }^{1}$
}

\author{
Expedition 301 Scientists $^{2}$
}

\section{Chapter contents}

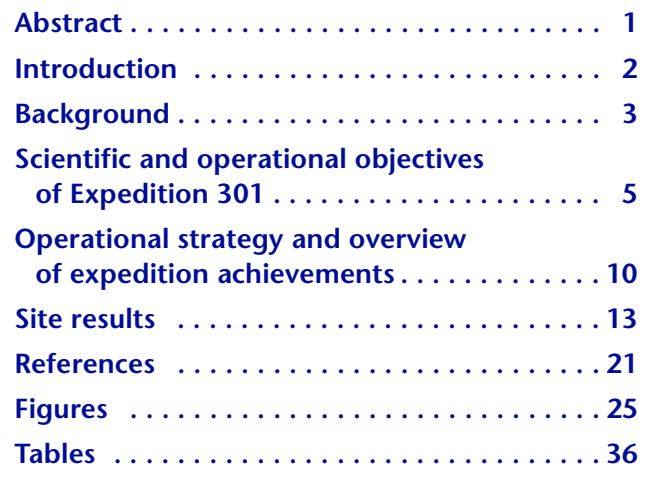

'Expedition 301 Scientists, 2005. Expedition 301 summary. In Fisher, A.T., Urabe, T., Klaus, A., and the Expedition 301 Scientists, Proc. IODP, 301: College Station TX (Integrated Ocean Drilling Program Management International, Inc.). doi:10.2204/iodp.proc.301.101.2005 'Expedition 301 Scientists' addresses.

\begin{abstract}
Integrated Ocean Drilling Program (IODP) Expedition 301 to the eastern flank of the Juan de Fuca Ridge was the first part of a multidisciplinary program designed to evaluate the formationscale hydrogeologic properties within oceanic crust; determine how fluid pathways are distributed within an active hydrothermal system; and elucidate relations between fluid circulation, crustal stratigraphy, alteration, microbiology, and seismic properties. The complete experimental program will comprise two IODP expeditions (the first having been Expedition 301, the second to be scheduled), an offset seismic experiment, and long-term monitoring and cross-hole tests facilitated with submersible and remotely operated vehicle expeditions extending 6-10 y after Expedition 301. During Expedition 301, we replaced one existing borehole observatory penetrating the upper oceanic crust and established two new observatories penetrating to depths as great as 583 meters below seafloor, or $318 \mathrm{~m}$ into basement. The observatories include long-term temperature and pressure logging systems, as well as fluid sampling and microbiology growth instruments. We also sampled sediments, basalt, pore fluids, and microbial communities; collected wireline logs; and conducted hydrogeologic tests in two basement holes. Shore-based studies include investigations of sediment and rock physical, chemical, and magnetic properties and will help us to learn where microbiological communities live in the crust and how these communities cycle carbon, alter rocks, and respond to fluid flow paths.

During a second drilling expedition, we will conduct the first multidimensional, cross-hole experiments attempted in the oceanic crust, including linked hydrologic, microbiological, seismic, and tracer components. After completion of drillship operations, we will initiate multiyear tests using the three-dimensional network of subseafloor observatories, allowing us to examine a much larger volume of the crustal aquifer system than has been tested previously. By monitoring, sampling, and testing within multiple depth intervals, we can evaluate the extent to which oceanic crust is connected vertically and horizontally; the influence of these connections on fluid, solute, heat, and microbiological processes; and the scale-dependence of hydrologic properties. This work is helping us to understand the nature of permeable pathways, the depth extent of circulation, the importance of permeability anisotropy, and the significance of hydrogeologic barriers in the crust.
\end{abstract}




\section{Introduction}

Thermally driven fluid circulation through oceanic crust profoundly influences the physical, chemical, and biological evolution of the lithosphere and ocean. Although much work over the last $30 \mathrm{y}$ has focused on hot springs along mid-ocean ridges, global advective heat loss from ridge flanks (crust older than 1 m.y.) is more than 3 times as large as that at the axis (e.g., Parsons and Sclater, 1977; Stein and Stein, 1994), and the ridge-flank mass flux is at least 10 times as large (Mottl and Wheat, 1994). Ridgeflank circulation generates enormous solute fluxes; alters sediments and basement rocks; supports a vast subseafloor biosphere; and influences thermal, mechanical, and chemical processes as plates are subducted (e.g., Alt, 1995; Cowen et al., 2003; Elderfield and Schultz, 1996). These processes crosscut all three primary themes motivating the Initial Science Plan for the Integrated Ocean Drilling Program (IODP). It is appropriate that the first expedition of IODP launches a new class of experiments designed to resolve the fundamental nature of fluid pathways in the crust and the dynamic influences of fluid circulation on Earth evolution.

Despite the importance of ridge-flank hydrothermal processes, little is known about the distribution of hydrologic properties; the extent to which crustal compartments are well connected or isolated (laterally and with depth); linkages between fluid circulation, alteration, and geomicrobial processes; or quantitative relations between seismic and hydrologic properties. IODP Expedition 301 explored these properties, processes, and relations and will help to address topics of fundamental interest to a broad community of hydrogeologists working in heterogeneous water-rock systems: the nature and significance of scaling phenomena, and the applicability of equivalent porous-medium representations of discrete fracture-flow processes.

Expedition 301 benefits from operational and scientific achievements of the Ocean Drilling Program (ODP), particularly ODP Leg 168, which focused on hydrothermal processes within uppermost basement rocks and sediments along an age transect across a young ridge flank (Davis, Fisher, Firth, et al., 1997). Leg 168 emphasized the fundamental physics and chemistry of ridge-flank hydrothermal circulation, and the associated alteration of sediments and shallow basement, through sampling, downhole measurements, and postdrilling observations within the upper tens of meters of basement. Although it was extremely successful (or perhaps because it was so successful), Leg 168 raised many new questions about hydrothermal properties and processes within ridge flanks. Expedition 301 focuses on the eastern end of the Leg 168 drilling transect, leveraging and extending results from Leg 168 in three primary ways:

- Through deeper drilling, coring, and downhole measurements within basement;

- By expanding the multidisciplinary mixture of ridge-flank research in a single area, including microbiological and biogeochemical analyses of sediments and basement rocks; and

- By establishing a three-dimensional (3-D) network of borehole observatories, to be used in long-term, crustal-scale experiments.

Expedition 301 comprises the first part of a multiyear program that includes two drilling expeditions; it is important to understand the complete experimental program to place Expedition 301 planning, operations, and results in context. A second IODP expedition to this area (to be scheduled) will add two additional boreholes and three new observatories to the 3-D network and will initiate a series of controlled, multidisciplinary, cross-hole experiments. The drilling components of this program were divided into two expeditions for several operational and scientific reasons, as described below. The first expedition was also intended to generate high-quality samples and data, to initiate a new phase of passive monitoring within ridge-flank basement rocks, and to address outstanding hydrogeologic and related questions.

The primary goals of Expedition 301 included the replacement of two borehole observatory systems established at ODP Sites 1026 and 1027 during Leg 168 and the establishment of two new observatories extending up to $400 \mathrm{~m}$ into basement at Site U1301 (Second Ridge) (Figs. F1, F2). This effort dovetails with plans under way to develop a cabled network of seafloor observatories across the Juan de Fuca plate, which should facilitate active and passive monitoring experiments for the next 10-20+ y. Other Expedition 301 goals included coring, sampling, and short-term downhole measurements in basement and limited collection of high-quality advanced piston corer (APC) sediment cores at Site U1301. Secondary (backup) objectives included drilling, coring, and sampling one or more holes in a region of known hydrothermal seepage, First Ridge (Figs. F1, F2), where sediment thins above a buried basement high, and drilling, coring, and sampling a much thicker sediment section to the east, Deep Ridge (Figs. F1, F2), where basement temperatures and alteration should be more extreme. We achieved all of our primary goals during Expedition 301, with the exception of replacing the borehole observatory in 
Hole 1027C (Table T1). This observatory can be replaced during the follow-up expedition.

\section{Background \\ Geological setting}

The Endeavour segment of the Juan de Fuca Ridge (JFR) generates lithosphere west of North America at $\sim 3 \mathrm{~cm} / \mathrm{y}$ (Davis and Currie, 1993; Johnson and Holmes, 1989). Topographic relief produces barriers to turbidites from the continental margin, resulting in the accumulation of sediment and burial of the eastern flank of the JFR within a region known as Cascadia Basin (Figs. F1, F2). Sedimentation rates were very high in Cascadia Basin during Pleistocene sea level low-stands, when the continental shelf was largely exposed and rivers and estuaries delivered large sediment fluxes directly to the deep ocean (Davis, Fisher, Firth, et al., 1997; Underwood et al., in press). This resulted in burial of oceanic basement rocks under thick sediments throughout much of the basin at an unusually young age. Oceanic basement is exposed to the west, where the crust is very young, and the sedimented seafloor is relatively flat to the east, except over (relatively rare) seamounts and other outcrops found near the eastern end of the Leg 168 transect (Figs. F1, F3). Basement relief is dominated by linear ridges and troughs oriented subparallel to the spreading center and produced mainly by faulting, variations in magmatic supply at the ridge, and off-axis volcanism (Davis and Currie, 1993; Kappel and Ryan, 1986). Basement relief is relatively low $( \pm 100-200 \mathrm{~m})$ near the ridge and higher $( \pm 300-700$ $\mathrm{m})$ to the east. Low-permeability sediment limits advective heat loss across most of the ridge flank, leading to strong thermal, chemical, and alteration gradients in basement.

The study area contains structural features common to most ridge flanks: extrusive igneous basement overlain by sediments, abyssal hill topography, highangle faulting, and basement outcrops. Although the work sites may not be typical of all ridge-flank settings (higher than average sedimentation rate, younger buried basement, and stronger lateral gradients in temperature), the field area is ideal, in part because of these extreme conditions. High gradients result in strong signals that rise above natural and experimental noise. The high sedimentation rate allows us to work on crust that is much younger than we could study otherwise, providing indications of ridge-crest as well as ridge-flank properties and allowing study of sites in different hydrologic settings that are close together. Because many experiments have been completed in this area (seismic, thermal, geochemical, and surface/borehole), we can "cali- brate" and compare interpretations based on different methods.

\section{Site survey for Expedition 301}

Marine geophysical surveys in this region began in the 1950s and 1960s, but the first detailed studies of this ridge flank intended to resolve the existence and influence of hydrothermal circulation were completed in mid- to late 1980s (Davis et al., 1989, 1992; Mottl and Wheat, 1994; Rohr, 1994). These studies included single- and multichannel seismic (MCS), gravity, magnetic, heat flow, and coring (with associated sediment and pore fluid analyses). Becker et al. (2000) show results from a 1992 John P. Tully survey that collected seismic data in the Second Ridge area, with an emphasis on nearby basement outcrops. Seismic results from two later surveys are summarized by Rosenberger et al. (2000). Davis et al. (1997a) compiled heat flow data collected between 1978 and 1995.

Extensive site surveys in support of Expedition 301 were completed by the Sonne and the Thomas G. Thompson in 2000 (ImageFlux and RetroFlux expeditions, respectively), and an additional seismic line across the Deep Ridge sites was collected during a Maurice Ewing expedition in 2002. Results from these most recent expeditions are summarized in Zühlsdorff et al. (this volume). Example seismic lines illustrate key features of sediments and uppermost basement at Expedition 301 sites (Fig. F4). The Second Ridge area is characterized by typical basement relief of 300-400 m, usually overlain by $250-600 \mathrm{~m}$ of sediment. To the north and south of Expedition 301 sites there are basement outcrops where basalt edifices rise above the seafloor (Davis et al., 1992; Mottl et al., 1998). Seismic data show that basement relief results in part from high-angle faults with offsets of tens to $>100 \mathrm{~m}$ (e.g., Fig. F4A, common depth points [CDPs] 570 and 600; Fig. F4B, CDPs 980 and 1020). There also appear to be at least two kinds of constructional structures on the top of basement throughout this area. First, there are small buried basement highs onto which sediment was subsequently draped. (Fig. F4A, CDP 450; Fig. F4B, CDP 840). There are also places where the uppermost basement reflector is unusually strong and flat. Becker et al. (2000) identified several such features in seismic lines crossing the Baby Bare outcrop and suggested that they were sills, and similar features appear in seismic data west of Site 1026 (Fig. F4B, CDPs 1100-1140).

The sediment section shows two main zones with distinctive seismic characteristics. The uppermost 200-300 ms two-way traveltime (TWT) includes prominent subhorizontal reflectors that clearly illus- 
trate the geometry of distributary channels for turbidites that flowed from the north. Sites 1026 and U1301 are located near the western edge of one such channel, which thickens considerably over Site 1027. There are patches of acoustically incoherent sediment within these channels, where subhorizontal layering is disrupted, and high-angle, small-offset faults that are present throughout the uppermost sediment (e.g., Fig. F4A, CDP 600). The lowermost 100-200 ms TWT of sediment is generally acoustically transparent, particularly where basement is deepest. Weak layering within this section onlaps and often pinches out against basement highs (see Zühlsdorff et al., this volume, for additional discussion and more examples of site survey data).

\section{Selected results from ODP Leg 168}

An $80 \mathrm{~km}$ transect comprising 10 sites was drilled on the eastern flank of the JFR during Leg 168 (Fig. F2). These sites were organized into three main ridgeflank environments. The western end of the drilling transect spanned a hydrothermal transition between hydrologically open and more isolated crust, documenting lateral gradients in basement temperatures, water compositions, and crustal physical properties. The rough basement area at the eastern end of the transect included considerable basement relief, large variations in sediment thickness, and isolated outcrops. The central part of the Leg 168 transect included sites located farther from regions of known basement exposure, where sediment thickness is more uniform.

Sediments recovered during Leg 168 included mainly sandy and silty turbidites and hemipelagic mud, with carbonate-rich intervals found just above basement at most sites (Davis, Fisher, Firth, et al., 1997; Underwood et al., in press). Sediments were generally unaltered by underlying hydrothermal processes, except for relatively subtle indications close to basement (Buatier et al., 2001). Shallow basement rocks were mainly fresh to altered pillow lavas and massive flows having a tholeiitic composition, but hyaloclastite breccia and a diabase sill were recovered at Sites 1026 and 1027, respectively. The extent of alteration generally increased from west to east, along with crustal age and basement temperature (Giorgetti et al., 2001; Hunter et al., 1999; Marescotti et al., 2000). Alteration minerals included clays, carbonates, zeolites, and sulfides.

Heat flow and upper basement temperatures along the Leg 168 drilling transect show several notable trends (Davis and Becker, 2002; Davis et al., 1999; Davis, Fisher, Firth, et al., 1997; Fisher et al., 1997; Pribnow et al., 2000). Heat flow values determined during Leg 168 increase over the western $20 \mathrm{~km}$ of the transect, from Site 1023 to Sites 1030 and 1031 (Fig. F2). These values vary from well below to well above standard reference curves for conductively cooling lithosphere (e.g., Parsons and Sclater, 1977; Stein and Stein, 1994). Heat flow in the middle and eastern end of the drilling transect is broadly consistent with reference curves, but local (sometimes large) variations in heat flow result from vigorous hydrothermal circulation within rugged basement below the seafloor (Fig. F2B). This circulation locally homogenizes uppermost basement temperatures such that seafloor heat flow patterns follow basement relief (e.g., Davis and Becker, 2002; Davis et al., 1997b; Spinelli and Fisher, 2004). Upper basement temperatures tend to increase monotonically from west to east along the drilling transect, from $\sim 15^{\circ} \mathrm{C}$ at Site 1023 to $\sim 64^{\circ} \mathrm{C}$ at Sites 1026 and 1027 (Fig. F2B) (Davis and Becker, 2002).

Thermal observations along the Leg 168 transect may be interpreted to indicate that the dominant direction of fluid flow is from the west to the east (Davis et al., 1999; Davis, Fisher, Firth, et al., 1997; Stein and Fisher, 2003), but pore fluid samples obtained from sediments collected immediately above basement, in combination with samples from basement boreholes and shallow sediment cores, are inconsistent with this interpretation (Fig. F2C). The western end of the drilling transect shows increasing alteration from west to east, consistent with rising temperatures in upper basement, but fluid recovered from Sites 1030 and 1031 is more altered than would be predicted on the basis of present temperatures in upper basement. In fact, this fluid has a geochemical signature consistent with alteration at $65^{\circ}-70^{\circ} \mathrm{C}$, much like the fluid recovered from Sites 1026 and 1027 and from springs on Baby Bare outcrop far to the east (Elderfield et al., 1999; Monnin et al., 2001; Mottl et al., 1998; Rudnicki et al., 2001; Wheat et al., 2000, 2002, 2003; Wheat and Mottl, 2000).

In addition, fluid samples that were subjected to ${ }^{14} \mathrm{C}$ analysis demonstrated that, although there is a progression in fluid age from west to east along the western end of the Leg 168 transect, fluids from Site 1030 are younger than those to the west and fluids from Site 1026 are younger still (Fig. F2C) (Elderfield et al., 1999). It is not possible for waters recharging the basement aquifer near the western end of the Leg 168 transect to gain "youth" as they travel to the east and become increasingly altered; another source of hydrothermal recharge is required. Wheat et al. (2000) showed that there is geochemical evidence for along-strike (south to north) fluid transport in basement. Fisher et al. (2003) presented thermal data and calculations based on the hydrogeologic properties of basement rocks and sediment and showed that recharge of Baby Bare outcrop (and Site 1026 
basement) fluids most likely occurs $\sim 50 \mathrm{~km}$ to the south, through Grizzly Bare outcrop (Fig. F3A).

Interpretation of fluid ages and rates of fluid flow in basement is difficult on the basis of ${ }^{14} \mathrm{C}$ data alone because fluids flowing within heterogeneous waterrock systems experience enormous diffusive and dispersive losses of radiotracers (e.g., Bethke and Johnson, 2002; Fisher, 2004; Fisher et al., 2003; Sanford, 1997; Stein and Fisher, 2003). Actual particle velocities within ridge-flank hydrothermal systems may be 100-10,000 times greater than indicated by simple plug-flow considerations of apparent fluid ages.

Collectively, geochemical data collected along the Leg 168 transect suggest that there are distinct regions of hydrothermal circulation within the upper basement and that fluids within each of these regions are hydrogeologically isolated from each other. The first region at the western end of the drilling transect contains relatively young water that has reacted minimally with the formation at $15^{\circ}-40^{\circ} \mathrm{C}$. This fluid becomes older, warmer, and more reacted to the east. The second region is associated with the first buried basement ridge below Sites 1030 and 1031. Fluid from this crustal region reacted with basement at temperatures of $65^{\circ}-70^{\circ} \mathrm{C}$, but the fluid must have cooled during or after ascent from depth because upper basement temperatures are only $40^{\circ} \mathrm{C}$. This fluid is young relative to the less reacted fluid to the west. The third chemically distinct region is within crust below Sites 1026 and 1027. This younger fluid mixes vigorously within upper basement at temperatures near $65^{\circ} \mathrm{C}$ and is chemically similar to fluid found seeping from nearby basement outcrops.

Although basement penetration was limited and there was no wireline logging in basement during Leg 168, borehole packer experiments and analyses of open-hole thermal data help to quantify local hydrogeologic properties (Becker and Davis, 2003; Becker and Fisher, 2000; Fisher et al., 1997). These experiments indicated near-borehole formation permeabilities of $10^{-14}$ to $10^{-10} \mathrm{~m}^{2}$, with the highest permeabilities determined for the youngest sites, at the western end of the drilling transect. The data are consistent with the rest of the global seafloor data set, helping to define two notable trends (Fig. F5): a decrease in uppermost basement permeability with increasing age and spatial scaling of permeability estimated using different methods (Becker and Davis, 2003; Fisher, 1998, 2005).

Borehole (Circulation Obviation Retrofit Kit [CORK]) observatories were installed during Leg 168 at western Sites 1024 and 1025 and at eastern Sites 1026 and 1027 (Davis and Becker, 2002, 2004). These sys- tems were instrumented to monitor borehole fluid pressure and temperature and to collect long-term fluid samples. Consideration of borehole fluid responses to tidal pressure variations and to regional tectonic events suggests that basement around the boreholes has higher effective permeability than determined with packer experiments and thermal logs (Davis et al., 2000, 2001). Because the different estimates of formation permeability were made using different methods and assumptions, it remains unclear if the apparent scaling tells us something important about the nature of basement permeability or is an artifact. This question is being addressed by Expedition 301 and related experiments.

Similarly high permeabilities, on the order of $10^{-9}$ $\mathrm{m}^{2}$, were inferred on the basis of steady-state numerical models that used a conductive proxy for coupled heat-fluid flow and extrapolation of relations between permeability and mixing efficiency at lower permeabilities (Davis and Becker, 2002; Davis et al., 1997b; Wang et al., 1997). Fully coupled, transient models of ridge flank circulation have shown that permeabilities this high need not be present throughout the upper crust; if fluid flow is highly channeled (Tsang and Neretnieks, 1998), considerable efficiency in heat transport can be achieved by advection through a small fraction of the crust (Fisher and Becker, 2000; Fisher et al., 1994; Spinelli and Fisher, 2004). In fact, having very high permeability distributed pervasively throughout the upper oceanic crust actually limits the efficiency of lateral fluid flow in transporting heat (Davis et al., 1999; Fisher and Becker, 1995; Rosenberg et al., 2000) and results in a convection direction that is inconsistent with observations (Spinelli and Fisher, 2004).

Hole 1026B yielded some of the first direct microbiological observations of ridge-flank fluids. Rock and fluid samples collected during Leg 168 indicated the possible presence of microbes (Bach and Edwards, 2003; Fisk et al., 2000), and a "BioColumn" experiment assessed microbial biomass and diversity in fluids venting from the CORK observatory. Cells collected from the BioColumn included bacteria and archaea, comprising nitrate reducers, thermophilic sulfate reducers, and thermophilic fermentative heterotrophs (Cowen et al., 2003). These tantalizing results encouraged study of the basement biosphere during Expedition 301.

\section{Scientific and operational objectives of Expedition 301}

This section highlights the fundamental scientific goals of Expedition 301 and related experiments. Some of the discussion includes operations that are 
to take place during future drilling and submersible/ remotely operated vehicle (ROV) expeditions. This information is included so that the rationale for Expedition 301 operations, and the extent of our successes, will be clear.

Despite extensive survey and drilling work in the eastern flank of the JFR prior to Expedition 301, we began the expedition with little information on the geological nature of permeable pathways, the depth extent of fluid circulation, the magnitude of permeability anisotropy, or the significance of hydrogeologic barriers in the crust. We knew that the upper oceanic crust is home to diverse microbiological communities, but we knew little about their populations or ecology or how their distribution relates to primarily crustal stratigraphy, fluid flow paths, water chemistry, or rock alteration. We did not know the concentrations and nature of nonliving organic matter within crustal fluids or how this material influences and is influenced by ocean carbon cycling. We did not understand the scales over which solute transport occurs in oceanic basement rocks or how transport and mixing are influenced by crustal structure and fabric. We did not know how to relate seismic velocities and velocity anisotropy to hydrogeologic properties.

Although some of these topics were addressed during Leg 168 and related surveys and experiments, earlier drilling in this area included penetration of only the uppermost few tens of meters of basement, leaving many questions unresolved. For example, CORK observatories installed at Sites 1026 and 1027 allow determination of upper basement temperatures and fluid pressures, but despite evidence for extremely rapid fluid convection in basement, it was not possible to determine if the dominant fluid flow direction is from Site 1026 to Site 1027, in the opposite direction, or perhaps perpendicular to both sites. Work during Expedition 301 and related surveys and experiments will help resolve this quandary and will address all of the topics listed above.

Basement work at Second Ridge sites (1026, 1027, and U1301) was given the highest priority and focused on numerous questions, including

- What is the primary lithostratigraphic and hydrogeologic structure of the upper $400 \mathrm{~m}$ of basement?

- What is the nature and influence of crustal alteration, and how is it related to fluid flow and associated processes?

- How have tectonic and magmatic processes contributed to formation and hydrogeologic evolution of the crust at Second Ridge?
- What are typical temperatures in the upper $400 \mathrm{~m}$ of basement, and what do these temperatures indicate about the vigor and directions of circulation?

- How does fluid chemistry relate to stratigraphy and alteration history, and are there distinct hydrogeologic compartments distributed vertically within upper basement?

- What microbiological communities exist within distinct crustal intervals, what is their ecology, and how are they related?

- How are solutes transported through upper basement, and what fraction of the crust contains the most important fluid conduits?

- What are the lateral and vertical gradients in pressure, temperature, and formation fluid chemistry along and across the Second Ridge?

Successfully addressing these and related questions required a combination of conventional and nonstandard scientific drilling approaches. In the rest of this section, we highlight unusual aspects of Expedition 301 and related experiments. Other components of the scientific program that are essential to the overall effort (e.g., petrographic analysis, inorganic geochemistry, and measurements of sediment temperature) are well established within the scientific drilling community and are not discussed. Some of the discussion includes work to be done during future drilling or submersible operations.

\section{Hydrogeologic testing}

Two primary kinds of active hydrologic tests were completed prior to Expedition 301 during the Deep Sea Drilling Project (DSDP) and ODP: slug tests and injection/flow tests (Becker and Davis, 2003; Fisher, 1998). Both kinds of tests have involved a single borehole and a drill string packer. Another form of flow test involves monitoring the movement of fluid into or out of a borehole resulting from natural pressure differences, after removal of a low-permeability sediment seal (e.g., Becker and Davis, 2003; Fisher et al., 1997). During a slug test, formation pressure is abruptly modified through rapid injection of a small fluid volume, and the pressure-time response of the isolated interval allows estimation of transmissivity $(T)$ and storativity $(S)$. Transmissivity is hydraulic conductivity (ease of fluid flow) multiplied by aquifer thickness within a horizontal system. Storativity is a measure of aquifer and fluid compressibility within a horizontal system. Although slug tests can be used to assess transmissivity in the immediate vicinity of a borehole, they are notoriously poor at constraining storativity and are not very useful in 
formations that are highly permeable. Single-hole injection and flow tests provide little information on storage properties, although they can be used to estimate bulk transmissivities with a radial scale that is somewhat greater than slug tests. The radius of investigation of any seafloor hydrologic test depends mainly on $T$ and $S$ and the duration of the test (Becker and Davis, 2003; Fisher, 1998).

CORK observations of formation pressure response to tidal forcing have also been used to estimate hydraulic diffusivity $(T / S)$ and storativity within oceanic crust (e.g., Davis et al., 2000), but as with interpretation of packer experiments, interpretation of passive CORK observations requires assumptions regarding the hydrologic homogeneity and isotropic nature of oceanic crust, as well as the geometry of the flow system and the magnitude, timing, and location of the source function. Observational data (geological, geochemical, and geophysical) demonstrate that the oceanic crust is highly heterogeneous and anisotropic (e.g., Becker and Davis, 2003; Fisher, 2004; Fisher and Becker, 2000). Numerical models have not helped to resolve discrepancies between properties estimated using different techniques because the models themselves are highly idealized. Applying a suite of techniques to a single area is the best way to assess the true nature of crustal permeability, including scaling phenomena (Fig. F5), and the validity of simplified representations of these systems.

Two ODP expeditions, Legs 169 and 171A, completed uncontrolled (and largely unplanned) crosshole experiments using CORK observatories (Fouquet, Zierenberg, Miller, et al., 1998; Moore, Klaus, et al., 1998). During each of these cruises, previously installed observatories monitored formation fluid pressure tens of meters or more from a site of active drilling. Expedition 301 was the first to be designed with cross-hole experiments being a primary goal. Through use of multilevel CORK observatories, we will isolate and monitor discrete depth intervals in basement, allowing assessment of both vertical and horizontal hydrogeologic connections between sites. Because we anticipated very high basement permeabilities and the perturbation resulting from drilling and observatory installation will take many months to dissipate (Davis and Becker, 2004), the cross-hole experiments cannot begin until the next drilling expedition. This will allow pressure, chemical, and thermal equilibration of the formation below newly installed CORKs so that small changes resulting from active experiments can be detected.

During a future drilling expedition, a $24 \mathrm{~h}$ packer test will be initiated in a borehole drilled at Site SR-2, between Sites 1026 and U1301 on Second Ridge.
This $24 \mathrm{~h}$ packer test will be $\sim 50$ times longer than any injection test into oceanic crust prior to Expedition 301. Based on a range of apparent bulk properties from packer tests, flow tests, tidal response, and numerical models (Becker and Davis, 2003; Becker and Fisher, 2000; Davis and Becker, 2002; Davis et al., 2000; Fisher et al., 1997), a readily measurable pressure response should be apparent at Sites 1026, 1027, and U1301 (Fig. F6). By subsequently waiting an additional 12 months for borehole equilibration, then opening one or more vent valves in a Site SR-2 CORK, we can release overpressured formation fluid for a year or more. This will initiate a free flow ("artesian") well test that will allow an even larger-scale assessment of crustal properties (Figs. F5, F6).

The results of these experiments will have implications well beyond oceanic crust, as there is an ongoing debate concerning the scaling of hydrogeologic properties within heterogeneous systems (Butler and Healy, 1998; Clauser, 1992; Neuman and Di Federico, 2003; Renshaw, 1998; Rovey and Cherkauer, 1995). Results of cross-hole testing in basement holes, combined with other observations and modeling, can also be used to test equivalent-porous-medium and other representations of the fractured upper crust. The seafloor is an ideal place to address these issues because a single test can be run for a very long time, effectively delineating the scale-dependence of hydrologic properties using a single measurement method. Such tests are generally not possible on land because of logistical and environmental concerns and a lack of demonstrated horizontal continuity. Generating cross-hole data within seafloor boreholes will also allow application of models developed for use in fractured aquifers (Barker, 1988; Moench, 1984) that have not previously been applied to the seafloor.

\section{Microbiological analyses}

Based on estimates of prokaryotic biomass in ODP sediment cores (Fig. F7), it has been suggested that the marine subseafloor biosphere is enormous, perhaps exceeding the cumulative biomass of all other ecosystems on Earth (Parkes et al., 1994; Whitman et al., 1998). This hypothesis is compelling, but it remains highly speculative, as it is based on global extrapolations from marine sediments at a relatively small number of sites. Extrapolation of microbiological conditions and densities from the sediment section into basement is also problematic. Cell densities in basement are likely to be low where fluids are old and carbon and nutrient sources are limited, but ridge-flank locations where basement fluids are young and nutrients are abundant might support considerably greater biomass. Also, the size of the 
subseafloor microbial biosphere does not equate to activity or importance. Cell-count studies in sediments have revealed cell densities exceeding $10^{5} / \mathrm{mL}$, but it is difficult to distinguish living cells from inactive or dead ones. Finally, the size of the subseafloor biosphere tells us little about the magnitude of biogeochemical fluxes into or out of the system.

Little is known about microbial community composition and microbial metabolism in hydrothermally active ridge flanks. The importance of thermal, lithologic, hydrogeological, and geochemical controls and relations between sediment- and basementhosted communities remains to be determined. Can cell-density trends from marine sediments be extrapolated into basement, or do cell densities increase (or decrease) rapidly once hydrologically active intervals are encountered (Fig. F7)? The only way to address these questions is through careful sampling and monitoring of sediments, basement rocks, and pore fluids. Six primary techniques are being used to assess the microbiological state of subseafloor environments as part of Expedition 301 studies:

- Total cell counts

- Cultivation experiments

- Fluorescence in situ hybridization (FISH)

- Molecular biological techniques based on ribonucleic acid (RNA) and deoxyribonucleic acid (DNA) sequences

- In vitro rate measurements of biological activity

- Downhole experiments to investigate growth, attachment, and microbial alteration of minerals

Recovering pristine formation fluids from oceanic basement is challenging because any formation having significant permeability will be deeply invaded by fluid pumped during drilling, casing, and other operations. These activities result in charging the formation with cold, oxygenated seawater and freshwater, the latter often used with drilling mud. Petroleum wells are typically "produced" for weeks or months to recover pristine formation fluids, and at present, this is the best approach for recovering uncontaminated formation fluid and microbiological samples from a hole in permeable ocean crust. Sites 1026 and U1301 are overpressured; fluids can be extracted for days to months to years from CORKs installed at these sites, minimizing contamination, allowing assessment of population changes over time, and facilitating long-term testing.

Expedition 301 and related experiments include three principal stages of microbiological and biogeochemical study. The first stage comprises biological sampling and analysis of the sediment column, in combination with pore fluid chemistry and in situ temperature measurement, to resolve the nature of sedimentary microbiological communities (e.g., D'Hondt, Jørgensen, Miller, et al., 2003) and compare them to those found in basement. Collection of uncontaminated sediment during drilling requires care but is possible with careful planning (House et al., 2003; Smith et al., 2000). With regard to Expedition 301 objectives, studies of microbial populations in sediment are most important in the near-basement environment.

The second stage of microbiological studies comprises sampling and analysis of basement rock. Collection of basalt samples for direct microbiological study is also complicated by contamination, but the use of perfluorocarbon tracer (PFT) during coring operations helps to determine which samples are more and less contaminated (Smith et al., 2000). Results will be compared to laboratory and in situ incubation experiments (Edwards et al., 2003, 2002) and to lithologic and alterations studies (e.g., Alt and Teagle, 1999, 2003; Fisk et al., 1998; Furnes and Staudigel, 1999), to relate basement alteration and microbial activity.

The third stage of microbiological studies involves time-series analyses of biological communities and formation fluids. Time-series studies are initiated at the time of CORK installation and will continue for years. CORK sensor strings contain continuous fluid samplers and microbiological substrate (Fisher et al., this volume). These samples will document community succession, biogeochemical response to formation recovery following drilling operations, and the role of microbes in the alteration of primary minerals. Additional sampling will occur when we open CORK valves at Site SR-2 1-2 y after installation of these systems. This will allow attachment of sensors and samplers at the seafloor to collect time-series data, fluids, and microbiological materials from multiple subsurface intervals. After completion of initial long-term flow experiments, additional seafloor valves at other sites can be opened. Through combined molecular biological and geochemical approaches and modeling (Cowen et al., 2003; Reysenbach and Shock, 2002), these samples will provide new insights into the responses of microbial ecosystems to geochemical conditions and the influence of microbial activity on fluid and basement geochemistry. Sampling and analysis of dissolved organic matter, an integrated and long-lasting signature of microbial activity, will elucidate carbon cycling in the crust. In addition to in situ incubation, flow-through incubation at the seafloor will allow system monitoring and manipulation and may allow additional options for temperature and pressure control once power to the site is provided by a (planned) cabled 
observatory system. This third stage of microbiological sampling and analysis is the only one that will collect high-quality samples from the hydrogeologically most important stratigraphic intervals in the crust.

\section{Tracer tests}

The extent of water mixing and water-rock interaction within an aquifer depends on properties such as effective porosity (the fraction of open space involved in fluid flow) and dispersivity (mechanical mixing and spreading of water and solutes by diffusion). Understanding these properties is critical to successful reactive-transport modeling and to understanding the age distribution of fluids in the seafloor, but these properties have never been assessed using tests in any DSDP or ODP hole. Effective porosity varies with flow direction in heterogeneous systems as a result of flow channeling (Tsang and Neretnieks, 1998) and must be tested directly. Like permeability, dispersivity varies as a function of test scale and must be determined at the scale of interest (Gelhar et al., 1992; Neuman, 1990; Novakowski, 1992). Tracer experiments will help to resolve these properties and to quantify rates of fluid transport in basement. We consider tracer tests in a broad sense to include the use of natural tracers, tests initiated through standard IODP operations (e.g., pumping surface seawater during drilling), and experiments involving injection and sampling of specific compounds.

Wheat et al. (2003) used major element chemistry of samples recovered by long-term deployments of OsmoSamplers in several sealed Leg 168 boreholes to estimate the rate of equilibration of borehole fluids and flow rates within the surrounding formation. Fluid chemistry changed rapidly during the first 4060 days after borehole sealing, as drilling fluid was replaced by formation fluid. A slower rate of chemical evolution was documented over the subsequent 1150 days as fluid continued to move through the borehole and borehole fluid in the open hole mixed vertically with fluid in the casing. Formation flow rates estimated from these experiments are comparable to estimates based on independent geochemical and thermal considerations (Wheat et al., 2003).

${ }^{14} \mathrm{C}$ was used as a natural tracer to estimate rates of transport along the Leg 168 transect (Elderfield et al., 1999), but consideration of nonconservative and mixing behavior must be included in analysis of flow within this heterogeneous crustal system (e.g., Stein and Fisher, 2003). For example, kilometer-scale tracer studies within a fractured granite aquifer suggest that the effective chemical diffusivity of the rock matrix may be extremely high (Becker and Shapiro, 2000; Shapiro, 2001). Rock transmissivity is highly hetero- geneous, and high effective diffusivity may result from preferential tracer migration along a few fractures, the rest being well connected only over short distances (Shapiro and Hsieh, 1998).

We have used (and will use in future experiments) different tracers in different holes and at different depth intervals so that single hole, cross-hole, and cross-level transport can be differentiated and quantified. Tracers injected during Expedition 301 included surface seawater, drilling mud, and PFT. Tracers being injected within CORK borehole observatories comprise a mixture of rare earth elements (Fisher et al., this volume). Tracers planned for injection at Site SR-2 during a future drilling expedition include $\mathrm{SF}_{6}$, rhodamine-WT, rare earth elements, and fluorescent microspheres, all of which are readily transported to the ship, environmentally benign, easily introduced into fluids pumped into the borehole, and detectable at low concentrations.

We are optimistic that tracers injected at Site SR-2 may be recovered at Sites 1026, 1027, or U1301 after a few years. Fluid flow velocities in basement along Second Ridge appear to be hundreds to thousands of meters per year (Fisher et al., 2003). Similar rates were inferred in basement along the western end of the Leg 168 transect (Stein and Fisher, 2003). By isolating limited depth intervals in the CORK observatories and instrumenting them with long-term samplers, we optimize chances for detection of crosshole fluid transport. In addition, each observatory is being used for single-hole tracer experiments (e.g., Altman et al., 2002; Novakowski et al., 1998). Interpretation of these kinds of tests, like those for crosshole tests, is accomplished using forward and inverse modeling techniques to obtain a match to the observed solute-time history (Becker and Shapiro, 2000; Clemo and Smith, 1997). Future tracer experiments can be run using seafloor pumps once the 3-D borehole network is established.

\section{Borehole and offset-vertical seismic profile experiments}

Much of what we know about oceanic crustal stratigraphy is based on seismic refraction and reflection data, but correlations between lithology and physical properties are often ambiguous. Relating outcrop or core properties to seismic-scale measurements is difficult (Jarrard et al., 2003), and relations between seismic and hydrologic properties are essentially unconstrained. There has long been evidence for anisotropy in seismic velocities in the upper crust, with faster velocities in the along-strike direction (e.g., Detrick et al., 1998; Stephen, 1985), but it remains to be determined whether the same crustal fabric includes significant pathways for fluid flow. Expedi- 
tion 301 included a conventional vertical seismic profile (VSP) experiment to help assess interval velocities and identify gross seismic layering in the upper crust; a future expedition will include an offset VSP to assess seismic velocity anisotropy. The conventional VSP uses one or more geophones clamped within an open or cased hole and a seismic source at the surface. We used the three-component Well Seismic Tool (WST-3) and an air gun source run from the drillship. Conventional VSP data from Sites U1301 and SR-2 may allow us to assess earlier interpretations of a seismically distinct boundary at $600 \mathrm{~m}$ into basement based on MCS data (e.g., Davis et al., 1996). An offset VSP will help to assess anisotropy in seismic properties.

\section{Operational strategy and overview of expedition achievements}

\section{Operational strategy}

Second Ridge Site U1301 was positioned $\sim 1 \mathrm{~km}$ south-southwest of Site 1026 (Table T2). Both sites are located above a buried basement ridge (Figs. F2, F3, F4), where sediment thins to $250-265 \mathrm{~m}$. The plan originally proposed for Site U1301 was to complete all operations in a single hole, so as to minimize the possibility of creating a hydrogeologic "short circuit" between basement and the ocean. However, discussion with engineering and operations personnel during initial planning stages for Expedition 301 in Fall 2003 led to development of a two-hole basement strategy for achieving primary technical and scientific objectives. One hole was intended to penetrate through the sediments and into uppermost basement, with a maximum penetration of $100 \mathrm{~m}$ into basement. The second hole was planned to be cased through the least stable parts of upper basement, allowing coring and downhole measurements at greater depths. This hole was originally proposed to extend $600 \mathrm{~m}$ into basement, but once the time requirements for the two-hole strategy became clear, the depth objective for the deeper Site U1301 hole was reduced to $300-400 \mathrm{~m}$ into basement.

Both holes were designed to be sealed with CORK observatories, the first monitoring uppermost basement and the second monitoring three additional zones at greater depths in the crust. These two holes were planned to be as close together as operationally feasible so that monitoring of conditions at different depths would be a true test of vertical connectivity within the crust. The actual distance between Holes U1301A (shallow) and U1301B (deep) ended up be- ing just $36 \mathrm{~m}$, which we believe to be the smallest intended spacing between adjacent reentry basement holes drilled in the history of DSDP and ODP.

The standard approach for establishing basement reentry holes is to first drill one or more exploratory holes to determine sediment properties and thickness. We decided to proceed directly with reentry holes at Site U1301 for several reasons. First, we already had a good understanding of sediment thickness and properties based on extensive site survey data and drilling at Site 1026 during Leg 168. Additional seismic coverage across Second Ridge provided clear indication of the depth to the sediment/basement contact. Second, we began at-sea operations $<24 \mathrm{~h}$ after leaving port and we were concerned that there would be insufficient time following remobilization of the JOIDES Resolution to prepare the laboratories and train shipboard scientists for core handling, particularly that involving microbiological sampling and analysis. Third, we wanted to save sediment coring options for times later in the expedition, perhaps when packer testing or observatory installation operations could not be completed because of weather or sea state and/or until we had confidence of achieving higher-priority basement and observatory objectives. Fourth, delaying sediment coring operations gave the scientific party a chance to learn more about regional geology and decide where such coring should take place. Finally, we did not want any holes adjacent to the observatories that might penetrate the sediment/basement interface and risk a hydrologic "short-circuit" between basement and the seafloor.

Basement drilling and coring plans were unconventional in other ways. First, we planned to drill the deeper hole first. This would allow us to assess the depth extent of unstable basement with a bottomhole assembly (BHA) well suited for this environment, including a tricone (noncoring) bit. This decision meant that we would not have core or logs from uppermost basement to help with assessing where to set casing and would rely instead upon drilling parameters and other qualitative indicators of formation stability. However, core recovery and log quality are notoriously poor in upper basement, and rapid drilling would provide the best chance for establishing a stable hole and installing casing. Also, by taking this approach we would have two opportunities for casing off unstable upper basement; if the first attempt failed, that hole could be used for shallow basement monitoring and we could offset and start a second hole.

Upper basement coring on Second Ridge had been attempted at Site 1026 during Leg 168 but yielded low recovery and an unstable hole that required a 
liner ( $51 / 2$ inch drill pipe) to keep the hole open. As it turned out, the first attempt to penetrate the upper $100 \mathrm{~m}$ of basement with a tricone bit during Expedition 301 was successful, but we failed to land the long $103 / 4$ inch casing string necessary to keep the hole open (see discussion below about casing seals and cementing). This hole became our shallow basement completion, with casing installed across only the upper $15 \mathrm{~m}$ of basement, and a second hole was started nearby for deeper basement penetration.

In addition to installing two CORK borehole observatories at Site U1301, we also planned to replace the earlier-generation CORK systems in Holes 1026B and 1027C. Replacing the CORK in Hole 1026B was a higher priority than that in Hole $1027 \mathrm{C}$ for several reasons. First, the Hole 1026B CORK began leaking soon after it was emplaced during Leg 168. The cause for the leak is not known, but it may have resulted from broken hydraulic tubing. As a result, it was not possible to determine with confidence the formation pressure in upper basement because an unknown amount of excess pressure leaked past the seafloor seal. Second, the instruments originally deployed in Hole 1026B had been removed years before Expedition 301, and there was no data logger installed for recording formation pressure.

In contrast, Hole $1027 \mathrm{C}$ remained well sealed below a Leg 168 CORK at the start of Expedition 301, and a pressure monitoring system was in place and working well. However, Hole 1027C includes a single monitored interval comprising two distinct hydrogeologic regions: uppermost ("true") oceanic crust and a shallower section of sills and sediment. Also, Hole 1027C may offer excellent potential for geochemical and microbiological monitoring of upper basement once casing packers are installed in the open hole because this will separate the long section of metal casing above from the monitored intervals. Replacement of the Hole 1027C CORK was scheduled for the end of Expedition 301 with the intent that time necessary for this operation might instead be needed for other CORK activities.

We also planned 2 days of sediment coring during Expedition 301, and an additional 1.5 days was scheduled as contingency time at the end of the expedition in case we had problems with CORK deployments or other basement operations. The primary focus of sediment coring was on microbiological and geochemical objectives, particularly in the interval close to basement, and we knew that rotary core barrel (RCB) and extended core barrel (XCB) coring would likely lead to significant contamination and poor recovery. We began Expedition 301 with a good lithostratigraphic record of Second Ridge from nearby Site 1026, so we were free to select a strategy intended to maximize other scientific (mainly sampling) objectives. Thus, we elected to attempt APC spot-coring through the sediment section at Site U1301, an approach that was largely successful. Sediment coring also provided an opportunity to assess the thermal state of the sediment column at Site U1301, which was important to hydrogeologic and observatory objectives.

\section{Overview of expedition achievements}

The most important objectives of Expedition 301 were achieved. We created two new basement holes, Holes U1301A and U1301B, that penetrate 108 and $320 \mathrm{~m}$ into basement, respectively, and instrumented each of these holes with multilevel CORK observatories (Fig. F8). We also replaced the CORK observatory in Hole 1026B. All of the holes have multiple isolated intervals to monitor and sample pressure, temperature, chemistry, and microbiology and will serve as observatory points for planned cross-hole experiments. In Holes 1026B and U1301A, the uppermost of two intervals comprise entirely cased hole-these intervals are to be monitored to help assess how well the CORK systems are operating and the extent to which the packers are sealed. Lower zones in these holes monitor conditions in basement. In Hole U1301B, we isolated basement zones comprising both the uppermost (brecciated and highly fractured) crust and the underlying, more massive rock. We cored upper basement in Hole U1301B with $\sim 30 \%$ recovery overall, typical for basaltic crust. Samples were collected for alteration, microbiology, paleomagnetism, and physical property studies, most of which will occur postcruise. Approximately $9 \%$ of recovered basement rocks were sampled as whole rounds and dedicated to microbiological analysis, a first for scientific ocean drilling. Logging data from the lower interval of Hole U1301B indicate that the hole is to gauge and that the crust is highly layered. Comparison to other upper crustal holes shows that we achieved our fundamental basement objective: separately isolating the upper and lower parts of the extrusive section of the crust. Packer experiments completed in Holes U1301A and U1301B show that the upper crust is highly permeable, but preliminary analysis suggests that there may be a decrease in bulk permeability with depth.

Actual operations differed from the plan outlined in the Expedition 301 Scientific Prospectus (Fisher, Urabe, Klaus, et al., 2004) in two significant ways: we did not replace the CORK in Hole 1027C and did not achieve as much basement penetration in Hole U1301B as originally hoped. Both of these deviations from the plan outlined in the Expedition 301 Scientific Prospectus primarily resulted from not being able to 
set $103 / 4$ inch casing deep into the crust with a seafloor seal inside 16 inch casing, as was planned, and from difficulties that ensued as a result of unsuccessful cementing operations that were attempted in the absence of a seafloor casing seal.

During planning for the expedition, we developed a two-hole strategy at Site U1301 to give us two chances to achieve our deeper crustal objectives. If the first hole became unstable, we could set shallow casing for the uppermost basement observatory and attempt a second hole to achieve the deeper objectives. As part of this strategy, we should have brought to sea two sets of mechanical casing seals, allowing $10^{3} / 4$ inch casing to seal inside 16 inch casing, so (1) we would not have to depend on cement to achieve a seal at the $103 / 4$ inch casing shoe in fractured and broken uppermost basement and (2) we could maintain the two-hole strategy and be able to make either hole the shallow or deep observatory. Despite extensive Expedition 301 planning, only one seal was fabricated for the expedition. Ultimately, we decided not to use the single mechanical seal. This seal appeared to have been built with incorrect tolerances and had not been test fit. The shipboard operations and engineering staff decided that it was best not to risk the installation by attempting to deploy the seal. Thus, completion of expedition goals at Site U1301 required successful cementing in upper basement.

One difficulty with using a conventional cementing approach in upper basement is that it requires pausing to attach the cementing swivel and manifold when running the $103 / 4$ inch casing into the open basement hole. After drilling Hole U1301A to target depth, we returned to the hole to run casing, but when we stopped advancing the casing to attach the cementing manifold (an operation requiring 16 min), we were subsequently unable to lower the casing the last few meters into the hole. We eventually shortened the casing string in Hole U1301A by 85 m, to case off only uppermost basement, and then attempted to cement this casing into place with a substantial length of open hole below. We could have tried to remove a single joint $(\sim 14 \mathrm{~m})$ of casing for the second attempt, but we decided to shorten the casing string by $85 \mathrm{~m}$ to increase our chances of being able to install the string (the area where we were stuck appeared to be well above the bottom of the hole) and to increase our chances of being able to get a good cement seal back up into the base of the 16 inch casing. We had similar difficulties running casing in Hole U1301B, but after considerable hole conditioning and two attempts with running long strings of $103 / 4$ inch casing, we finally landed a fulllength casing string. However, the cementing job at the base of the 103/4 inch casing here was not successful, in that the cement did not form a solid bond with the formation around the casing shoe. Subsequent drilling out of the cement in the casing and RCB coring operations caused the casing to unscrew from the bottom, and $\sim 100 \mathrm{~m}$ of the casing fell $5-6 \mathrm{~m}$ to the bottom of the hole, leaving a gap in the $103 / 4$ inch casing string. This led to numerous difficulties during pipe trips and forced an early end to coring operations in Hole U1301B to attempt remedial cementing.

In addition, the $10^{3 / 4}$ inch casing gap led us to run dozens of bowspring centralizers on the $500 \mathrm{~m}$ long CORK casing string initially run into Hole U1301B in order to centralize the CORK casing/packer/screen assembly as it passed through the casing gap. After reentering the hole with the bottom of the CORK, something hung up, preventing the CORK from passing freely into the hole. The $4 \frac{1}{2}$ inch casing failed, and the rest of the CORK casing was run out onto the seafloor. We suspect that the failure was caused by the bowspring centralizers hanging up in the throat of the reentry cone or by accumulating too much friction once the first six to eight were run into the $103 / 4$ inch casing. It is clear that the failure happened long before the end of the CORK encountered the gap in the base of the $103 / 4$ inch casing. The fundamental problem was that the CORK casing string was deployed without sufficient weight at the bottom to "pull" the casing into the hole and keep the casing string in tension. This lack of weight also made it difficult for the drillers to observe a weight loss when it hung up.

We used the CORK head from the first CORK attempt in Hole U1301B and other parts intended for use in Hole $1027 \mathrm{C}$ to build a new CORK observatory for Hole U1301B. For this string we added 10,000 lb of drill collars on the bottom and used only three spring centralizers, and it was deployed into the hole with no major problems. We finished operations in Hole U1301B by cementing the CORK observatory into the reentry cone in an attempt to seal between the 16 inch and 103/4 inch casing strings. We noted that CORK deployment in Hole 1027C would benefit from limited deepening of the hole so that weight might be added to the bottom for its CORK casing string, but we lacked both time and components to complete work in Hole 1027C during Expedition 301.

With primary goals achieved during Expedition 301, we are ready to press forward with the second half of the experimental program, including multidisciplinary, cross-hole experiments. A second drilling expedition will also replace the CORK in Hole 1027C and complete additional remedial cementing in the 
cones around the CORKs in Holes U1301A and $\mathrm{U} 1301 \mathrm{~B}$ to assure that these systems are fully sealed for the subsequent $5+\mathrm{y}$ of hydrogeologic experiments.

\section{Site results}

\section{Site 1026}

Three CORK borehole observatories were installed during Expedition 301, in Holes 1026B, U1301A, and U1301B (Fig. F8). The first of these systems replaced a CORK observatory deployed during an earlier cruise; the second and third are in newly drilled and cased holes. The new Hole 1026B CORK system was the simplest of the systems deployed during Expedition 301 . It comprised a CORK-II body with $4 \frac{1}{2}$ inch casing extending to 201.5 meters below seafloor (mbsf) and a single packer element set in casing near the bottom of the $4 \frac{1}{2}$ inch casing. No $4 \frac{1}{2} 2$ inch casing was installed below the packer element sub because the hole was completely cased to a depth below the liner and there was no need to provide additional protection for the instruments hanging below the bottom plug.

The umbilical run in Hole 1026B comprised a single $1 / 2$ inch packer inflation line and three $1 / 4$ inch pressure-monitoring and fluid-sampling lines. The three $1 / 4$ inch lines were run through the single packer and ended in small wire-wrapped screens that were attached just below the inflation element. All of the CORK systems deployed during Expedition 301 included nine pass-throughs within the packers and across the upper $103 / 4$ inch casing seal so that we could use a single design for these systems and achieve sampling and monitoring goals within multi-interval CORKs. Most of the extra passthroughs in the Hole 1026B CORK were capped, but one line through the $103 / 4$ inch casing seal was plumbed into a two-way valve in the CORK head so that during a future submersible or ROV dive expedition it will be possible to check pressure below the casing seal but above the packer element. If the pressure monitored below the packer is different from that above the packer, this will give a positive indication that the CORK system is properly sealed. As with all other valves in the CORK head, this one was left open during deployment to prevent air from being trapped in the sampling and monitoring lines.

The Hole 1026B instrument string included three OsmoSampler packages and two autonomous temperature loggers. One OsmoSampler contains copper coils for gas sampling, another has Teflon tubing for fluid sampling and tracer injection, and the third contains microbiological growth substrate and an acid-addition OsmoSampler for metals analyses.

\section{Site U1301}

Work at Site U1301 comprised operations in and around four holes (Table T2). Hole U1301A operations included penetration of $262 \mathrm{~m}$ of sediment and the upper $108 \mathrm{~m}$ of basement, installation of casing, short-term hydrogeologic testing, and emplacement of a single-level CORK-II borehole observatory. Hole U1301B penetrated 265 of sediment and $318 \mathrm{~m}$ of basement. This hole was RCB cored over the lower $232 \mathrm{~m}$ of basement, logged, subjected to hydrogeologic testing within multiple depth intervals, and fitted with a multilevel CORK-II borehole observatory. Hole U1301C was discontinuously APC cored to 265 mbsf, and in situ temperatures were determined to evaluate the thermal state of uppermost basement. Hole U1301D was APC spot-cored to recover sediment from an interval that had not been cored in Hole U1301C.

\section{Sediments}

The lithologies of sediments at Site U1301 were found to be virtually the same as those cored at Site 1026 during Leg 168, 1-2 km to the north along the same buried basement ridge, comprising fine- to coarse-grained turbidites, debris flows, and hemipelagic clay. Resampling much of the same sedimentary interval during Expedition 301 was justified because APC coring had not previously penetrated below 100 mbsf in this area, and we wished to collect high-quality samples for microbiological and geochemical analyses, especially in the interval close to the sediment/basement interface and the underlying crustal aquifer. Time constraints prevented continuous coring of the complete sedimentary section, but intervals that were cored generally yielded excellent recovery and high-quality samples. Exceptions to this rule included intervals where coarse sand or gravel prevented complete penetration of the APC barrel.

Silt- and clay-rich APC cores from Holes U1301C and U1301D are of exceptionally high quality, even from depths below 250 mbsf. Cores recovered from sandy and gravely intervals are generally of poorer quality and often include intervals within which there is complete resuspension and settling of clastic particles. Because of discontinuous coring, irregular recovery, and extensive whole-round sampling, we were unable to determine well-constrained lithologic boundaries for the primary stratigraphic units in Hole U1301C. Unit I is an upward-fining turbidite 
sequence with gravel interbeds, and Unit II is a hemipelagic clay sequence. The true boundary between Units I and II is present somewhere within the noncored interval between 197 and 236 mbsf. Its approximate location may be inferred from its equivalent depth in Hole 1026C (216 mbsf).

There are differences between the lithologies recovered at Site U1301 and those documented at Site 1026. The coarsest layers recovered at Site 1026 comprised mainly muddy sand and mud clasts, whereas coarse sediments from Hole U1301C included clasts of serpentinite, green amphibolite, quartzite, felsic volcanics, calcareous sandstone, and shallow-water shell fragments. One explanation for the difference is that the two sites sampled different parts of the turbidite distributary channel network, but it seems just as likely that coarse intervals were simply not recovered during XCB and RCB coring during Leg 168. The other significant difference was the greater thickness of the hemipelagic clay unit, which is at least $27 \mathrm{~m}$ thick in Hole U1301C but was only $13 \mathrm{~m}$ thick at Site 1026. This may result from subtle differences in basement relief and depositional regime, which influence whether hemipelagic clay or finegrained turbidites dominate deposition over basement highs (e.g., Giambalvo et al., 2000; Spinelli et al., 2004).

Pore water chemical-depth profiles from Site U1301 are similar to those from ODP Site 1026. As observed in numerous DSDP and ODP holes drilled to basaltic basement, there are two biogeochemical zones identified on the basis of steep geochemical gradients at the seawater/sediment and sediment/basement interfaces. The gradients are particularly well defined in the dissolved sulfate, manganese, and iron profiles. The downhole pattern of sulfate concentrations indicates active sulfate reduction at $\sim 50$ and $\sim 125$ mbsf and diffusive sources from bottom seawater and the basaltic formation fluid, respectively. Concentrations of dissolved barium are high in between these depths. Alkalinity, chlorinity, and ammonium profiles are also nearly identical at Sites U1301 and 1026 and have end-member compositions that approach those of spring fluids from Baby Bare outcrop $6 \mathrm{~km}$ away.

However, there are several significant differences in the profiles from these two sites for the minor elements, most notably for dissolved iron. Data from Site U1301 have a maximum iron concentration of $133 \mu \mathrm{mol} / \mathrm{kg}$, compared to $14.8 \mu \mathrm{mol} / \mathrm{kg}$ at Site 1026. This highlights the importance of squeezing the sediment under a nitrogen atmosphere. There are differences between chemical profiles from Site U1301 and Site 1026 in Mn, B, Sr, and Li concentrations. For these elements, the upper portion of the profiles are identical, but there are significant differences present within the basal sediments. These differences are unlikely to have resulted from sampling artifacts, as was the case for iron, because these elements do not oxidize rapidly like iron. The carbon content of the pore water increases in the first $40 \mathrm{~m}$ of sediment, reaching a maximum at 47 mbsf. From 179 mbsf to the bottom of the hole, dissolved carbon concentrations are very low.

The depth profile of methane varies inversely with sulfate and indicates the presence of two sulfate/ methane interfaces. Methane concentrations are low in the upper part of the sediment but increase sharply in the depth interval between 60 and 70 mbsf and reach a maximum near 100 mbsf. Higher molecular weight hydrocarbon gases were not detected in samples from Site U1301. The highest methane concentrations are present within the interval where sulfate is nearly depleted. This relationship indicates that the methane results from microbiological production. The disappearance of almost all of the methane at the depths of sulfate depletion indicates that most of this methane is likely consumed by anaerobic methane oxidation. Consequently, methane concentrations remain low in zones without active methanogenesis.

The solid phase of recovered sediments has relatively low organic carbon, nitrogen, and hydrogen contents. Organic carbon contents are highest close to the sediment/water interface $(0.9 \mathrm{wt} \%)$ but decrease rapidly and fluctuate around $0.3 \mathrm{wt} \%$ throughout the sediment column. Total nitrogen averages $\sim 0.04$ wt $\%$ and has a depth trend similar to organic carbon. Calculated atomic $\mathrm{C} / \mathrm{N}$ ratios generally indicate organic matter of marine origin. In some discrete sediment layers, however, elevated $\mathrm{C} / \mathrm{N}$ ratios indicate a significant input of terrestrial organic matter. We also find distinct layers with highly elevated carbonate contents below the postulated lower zone of anaerobic methane oxidation. Observed carbonate peaks coincide with elevated carbonate levels found at Site 1026 below the lower zone of anaerobic methane oxidation and at the sediment/basement interface.

Microbiological samples were collected from all sediment cores. Total cell counts decreased slightly with depth, from near-surface concentrations of $7.5 \times 10^{8}$ to concentrations of $1.8 \times 10^{7}$ cells $/ \mathrm{cm}^{3}$ at $248 \mathrm{mbsf}$. Overall, the profile of microbial cell densities follows a trend similar to that defined for other ODP sites. Tiny coccoid-shaped cells dominated throughout the sediment column. Numbers of rod-shaped cells fluctuated strongly. Aggregates of up to 30 microbial cells were detected in four horizons between 63 and 90 mbsf. Interestingly, an increase in cell numbers 
was observed near the sediment/basement interface. This increase in biomass may be supported by upward flux of electron acceptors from hydrothermal fluids in the underlying bedrock. Sulfate may be an important oxidant in the deepest part of the sediment column, illustrating how water in the basaltic crust might support microbial growth in overlying sediments.

Approximately 1000 enrichment cultures of indigenous microorganisms were inoculated on board using three methods. Samples were cultured in various forms using different media and incubation temperatures ranging from $5^{\circ}$ to $85^{\circ} \mathrm{C}$. None of the anaerobically incubated enrichments showed growth during Expedition 301. The incubation time was probably too short for most of the microorganisms to grow, and these studies will be continued on shore.

PFT was pumped during all coring operations to help in evaluating core contamination. PFT concentrations were evaluated across the cut faces of the cores, and results of these tests indicate that contamination was generally minimal, usually indicating a ratio of introduced to native cells of $10^{-9}$ or fewer. We found no relationship between drilling fluid contamination and core depth or lithology (clay versus sand).

Physical properties from Hole U1301C are highly bimodal, with clay- and sand-rich sediments showing distinctive trends for most measurements. Magnetic susceptibility data show trends that are typical for turbidites, with higher values in the coarse sandy layers and lower values in clay-rich layers. In contrast, natural gamma radiation levels were not particularly helpful in distinguishing primary lithology. Bulk density of the clay layers increases systematically from $1.4 \mathrm{~g} / \mathrm{cm}^{3}$ at the seafloor to $\sim 2 \mathrm{~g} / \mathrm{cm}^{3}$ at 100 mbsf and correlates with a $30 \%$ decrease in porosity over the same depth interval. The porosity of sand layers remains relatively constant at $\sim 40 \%$ to a depth of 115 mbsf. Because of time and operational constraints, two large continuous sections below 100 mbsf were not cored, prohibiting analysis of trends at greater depth. Bulk density values from clay lithologies recovered in the $30 \mathrm{~m}$ above basement vary slightly about a mean of $1.9 \mathrm{gm} / \mathrm{cm}^{3}$. The bulk density of sand layers is relatively consistent at $2.0 \pm 0.1$ $\mathrm{g} / \mathrm{cm}^{3}$. Grain density is remarkably consistent at 2.8 $\pm 0.1 \mathrm{~g} / \mathrm{cm}^{3}$ regardless of depth or lithology. The higher than expected grain density could be attributable to pyrite, which has a grain density of $\sim 5 \mathrm{~g} / \mathrm{cm}^{3}$.

Thermal conductivity was strongly controlled by lithology, with values for clay being significantly less than values for sand, averaging $1.12 \pm 0.12$ and 1.53 $\pm 0.19 \mathrm{~W} / \mathrm{m} \cdot \mathrm{K}$, respectively. A systematic increase of thermal conductivity is apparent in the upper 100 mbsf within clay-rich layers. A matrix thermal conductivity of $\sim 2.5 \mathrm{~W} / \mathrm{m} \cdot \mathrm{K}$ was indicated for clay-rich layers, a value $\sim 1 \mathrm{~W} / \mathrm{m} \cdot \mathrm{K}$ less than that estimated by Shipboard Scientific Party (1997) in Hole 1026A. Pwave velocity values range from $\sim 1480$ to $1780 \mathrm{~m} / \mathrm{s}$ over the $265 \mathrm{~m}$ cored interval, with an increase of $\sim 10 \%$ within the uppermost 50 mbsf. We found no evidence for velocity anisotropy. Undrained shear strength also increased with depth through the sediment section.

Two attempts to determine in situ temperatures in Hole U1301C were made with the APC temperature tool and three were made with the Davis-Villinger Temperature Probe (DVTP). One of each kind of measurement was unsuccessful, but the remaining data were sufficient to determine both the temperature of uppermost basement and heat flow through the sediments. The upper basement temperature is $\sim 62^{\circ} \mathrm{C}$, approximately the same as those measured at nearby Sites 1026 and 1027, and heat flow through the sediments is $280 \mathrm{~mW} / \mathrm{m}^{2}$ and entirely conductive.

\section{Basement}

The geology of the uppermost $85 \mathrm{~m}$ of basement is poorly known at Site U1301 because no coring was attempted from the sediment/basement interface to this depth. The decision to drill and case off uppermost basement at Site U1301 was made during planning for Expedition 301 on the basis of general and local experience, as discussed earlier (see "Operational strategy"). RCB core recovery was only 5\% within the upper $40 \mathrm{~m}$ of Hole 1026B (Shipboard Scientific Party, 1997), and that hole required installation of a liner at depth to keep basement "open" for testing and monitoring.

Records of drilling penetration rates within the upper $100 \mathrm{~m}$ of basement at Site U1301 provide limited lithostratigraphic insight (Fig. F9). Penetration rates $<3-4 \mathrm{~m} / \mathrm{h}$ generally corresponded to relatively massive rock and stable hole conditions, whereas penetration rates $>8-10 \mathrm{~m} / \mathrm{h}$ were usually accompanied by hole instability. Although there is not a one-toone correspondence between penetration rates at equivalent basement depths in the two holes, there are gross similarities. For example, the interval from 55 to $65 \mathrm{~m}$ into basement drilled relatively slowly in both holes, whereas the interval from 65 to $80 \mathrm{~m}$ into basement drilled much more quickly. We initially attempted to place casing across this fast-drilling interval in Hole U1301A but failed to land the original casing string. We had to shorten this string and cased off only the uppermost $15 \mathrm{~m}$ of basement 
in this hole. We subsequently cased of most of this fast-drilling interval in Hole U1301B.

Basement was cored from 351 to 583 mbsf (86 to 317.6 meters subbasement [msb]) in Hole U1301B. The $69.1 \mathrm{~m}$ of recovered core, comprising recovery of $30 \%$, consisted of (1) basalt-hyaloclastite breccia, (2) aphyric to highly phyric pillow basalt, and (3) massive basalt. Eight basalt units were defined on the basis of changes in lava morphology, rock texture, and grain size (Fig. F10). Pillow lava units (Units 1, 3, 5, 7 , and 8 ) were subdivided based on changes in phenocryst mineralogy and abundances. Massive lava units (Units 2, 4, and 6) were subdivided into individual cooling units, based on the presence of chilled margins.

Pillow basalt was the most abundant rock type recovered from Hole U1301B. Pillow lavas were identified by the presence of curved chilled margins, oblique to the vertical axis of the core, with perpendicular radial cooling cracks. Pillow fragments have dominantly hypocrystalline textures with a glassy to microcrystalline groundmass. They are sparsely to highly plagioclase \pm clinopyroxene \pm olivine phyric. Observed basalt textures vary from glassy to hyalophitic (typically with sheaf-spherultic or plumose textures) to glomeroporphyritic, seriate, and intersertal. The pillows are sparsely vesicular, containing $1 \%-5 \%$ round gas vesicles, and slightly to moderately altered. Alteration styles include interstitial groundmass replacement, vesicle fill, vein formation (with associated alteration halos), and the complete replacement of olivine phenocrysts. An almost complete section through a single pillow was recovered in one $45 \mathrm{~cm}$ long interval of essentially continuous core.

Several pieces of basalt-hyaloclastite breccia were recovered and defined as subunits. These thin breccias ( $<1 \mathrm{~m}$ of recovered core) are composed of clasts of basalt that are similar to the underlying basalts, some with glassy margins. Given the low recovery of these intervals, and the dedicated use of most of the recovered rock for microbiological analysis, it is not possible to determine the relationship between the hyaloclastite portions and underlying lavas, specifically whether or not they are part of the same cooling unit.

Massive basalts consist of continuous sections of up to $4.5 \mathrm{~m}$ of similar lithology, which increases in grain size toward the center of the flows. Some massive flows have upper and/or lower planar glassy chilled margins. High recovery, up to $100 \%$ in one case, allows individual lava flows or cooling units to be distinguished. Mineralogically, the massive lavas are very similar to the sparsely phyric pillow basalts, containing plagioclase, olivine, and clinopyroxene as phenocryst as well as groundmass phases. The massive basalts are sparsely to highly vesicular, with an average of $1 \%-5 \%$ round gas vesicles, up to $3 \mathrm{~mm}$ in diameter. The vesicles are generally concentrated in the upper portions of the flows, but one unit has a distinct $20 \mathrm{~cm}$ wide band in its center, of which $\sim 15 \%$ is vesicles. The massive flows are slightly to moderately altered and exhibit similar alteration styles to the pillow basalts: vesicle fill, vein formation (and the development of associated alteration halos), and the complete replacement of olivine phenocrysts. However, the massive basalts contain fewer fractures and veins than the pillow basalts, allowing better core recovery and the retrieval of individual pieces up to $94 \mathrm{~cm}$ long.

Geochemical analysis of basalt samples indicates that they are normal depleted mid-ocean-ridge basalt (MORB). The consistency of cross plots such as $\mathrm{TiO}_{2}$ versus $\mathrm{Zr}$ suggests that all the basalt recovered from Hole U1301B came from the same magmatic source. All of the basement rocks recovered from Hole U1301B have undergone alteration. Most pieces are slightly to moderately altered, with secondary minerals (1) lining or filling vesicles and cavities, (2) filling fractures and veins, (3) replacing phenocrysts, or (4) replacing interstitial mesostasis and glass. Thin section observations indicate that the degree of alteration varies from $\sim 5 \%$ to $25 \%$, excluding the hyaloclastite breccia, which is $\sim 60 \%$ altered. The freshest rocks are the interior, dark gray cores of most pieces, which have a saponitic background alteration. Fresh olivine appears only as microphenocrysts in some glass margins and elsewhere is completely replaced. Clay minerals are the most abundant secondary minerals and are the principal constituent of all four styles of alteration (vesicle fill, vein fill, phenocryst replacement, and background mesostasis alteration). Saponite is the most abundant of the clay minerals, identified in every thin section. It is present as cryptocrystalline granular or fibrous aggregates and varies in color from black to dark greenish brown to pale blue in hand specimen and tan-brown to olive-green in thin section. Saponite lines or fills vesicles, is the most common olivine phenocryst replacement, appears in mono- and polyminerallic veins, replaces mesostasis and glassy margins, and forms the matrix of the hyaloclastite breccia.

Celadonite, bright blue-green in hand specimen and bright green in thin section, also fills vesicles and veins and replaces olivine phenocrysts and mesostasis. However, celadonite is typically restricted to the alteration halos, frequently present as intergrowths with saponite and/or iron oxyhydroxide. Iddingsite, a mixture of clay minerals and iron oxyhydroxide, is 
the second most abundant alteration product identified in Hole U1301B cores, producing a characteristic red-orange or reddish brown color in both hand specimen and thin section. It fills veins and vesicles, stains primary minerals, and is intergrown with the clays that replace olivine. Calcium carbonate was observed in only six cores, filling vesicles and veins and as a minor component of the basalt-hyaloclastite breccia matrix. Secondary pyrite was observed lining vesicles, as fine grains within saponite vesicle linings, with saponite \pm calcium carbonate in veins, and as disseminated fronts bounding some alteration halos. Zeolites (analcime and phillipsite) were tentatively identified in several basalt samples in veins as well as in the matrix of the hyaloclastite breccia.

A total of 2301 veins were identified in the core recovered from Hole U1301B, with an average frequency of 31 veins $/ \mathrm{m}$ of recovered core. Saponite is the most abundant vein-filling mineral, present in $98 \%$ of the veins. Iron oxyhydroxide was documented in 1010 veins, whereas celadonite was identified in only 93 veins, typically appearing with iron oxyhydroxide \pm saponite. Pyrite was observed in 59 veins and is typically associated with saponite. Calcium carbonate was observed in 38 veins, with saponite \pm pyrite. Clay-bearing veins are ubiquitous in the rocks recovered from Hole U1301B and vary in width from $10 \mu \mathrm{m}$ to $6 \mathrm{~mm}$, averaging $0.2 \mathrm{~mm}$. The maximum width of the simple dark green saponite veins is $2 \mathrm{~mm}$. These predominantly narrow veins are prolific in pillow fragments, with saponite filling many of the radial cooling cracks along pillow margins. Iron oxyhydroxide- and celadonite-bearing clay veins vary in width from $10 \mu \mathrm{m}$ to $6 \mathrm{~mm}$, and average $0.2 \mathrm{~mm}$. They are most common in the pillow lavas, but the most spectacular iron oxyhydroxidebearing vein appears in a massive lava flow and is 6 $\mathrm{mm}$ wide with a $10-25 \mathrm{~mm}$ wide alteration halo. Goethite and minor celadonite were identified within this vein by X-ray diffraction.

The dips of 647 veins and fractures were measured in the recovered cores from Hole U1301B. Four types of fractures were distinguished in the cores: (1) veins flanked by alteration halos, (2) veins not flanked by alteration halos, (3) calcite-filled shear veins with slickenfibers (microfaults with contemporaneous displacement and secondary mineral growth), and (4) microveins $(<0.05 \mathrm{~mm}$ wide), identified in thin sections. Haloed veins were the most frequently observed structures, typically $3-10 \mathrm{~mm}$ wide and predominantly black to dark green, depending on the secondary clay alteration assemblage present. Nonhaloed veins were identified in the massive lavas and some pillow lava pieces. Calcite-filled shear veins or faults were identified in three of the recovered pieces. These steeply dipping structures have calcite slickenfibers or overlapping fibers. The fibers define a steeply plunging lineation with asymmetrical calcite crystals, indicating dip-slip motion. This extensional style of deformation may relate to regional normal faulting. Interestingly, a compilation of dip angles shows that rocks recovered from Hole U1301B have dominantly high-angle fracture dips, despite the expected bias toward sampling of low-angle features by coring a vertical hole.

Paleomagnetic measurements of basement rocks from Hole U1301B were made on 158 discrete samples. Characteristic remanent magnetization directions from the samples thought to be most reliable are highly scattered when plotted versus depth in the hole. The mean inclination within the upper 100 $\mathrm{m}$ of the cored interval is $50^{\circ}-60^{\circ}$, somewhat shallower than that expected based on the current (and past) latitude of the site, and data from the lowest $150 \mathrm{~m}$ of the hole show a more complex pattern. There is more variability in apparent inclinations, and some intervals include dominantly negative inclinations. Given the known basement age, it seems unlikely that these rocks cooled from magma during a period of dominantly reversed magnetic polarity. It might be supposed that there could have been short periods of magnetic reversal within dominantly positive magnetic polarity, but the samples yielding negative inclinations are often closely associated with other samples that yielded positive inclination.

Two other explanations are self-reversal or remagnetization. Reversed magnetization could occur if alteration and magnetic mineral replacement occur during a period of time with an opposite magnetic polarity. This seems the most likely explanation for negative inclinations in some Hole U1301B samples because geologic observations indicate pervasive hydrothermal alteration and because shipboard paleomagnetic studies point to multiple magnetization components as well as the appearance of pyrrhotite in some samples. Pyrrhotite is a mineral that is a common by-product of the dissolution of magnetic minerals, such as magnetite, and the conversion of the iron into iron sulfide minerals. If this interpretation is correct, then the negative inclinations may correspond to zones where greater alteration has occurred.

Of $69.1 \mathrm{~m}$ of hard rock core recovered in Hole U1301B, 9\% was taken as whole-round samples on the catwalk or in the splitting room and dedicated to microbiological analyses. Shipboard scientists attempted to make total cell counts in samples fixed in ethanol and containing small pieces of basalt and basalt that had been crushed to powder. However, 
the material showed high amounts of cell-like structures (small crystals and needles) with strong fluorescent signals. Even after testing a variety of dilutions that had been filtered and stained, it was impossible to distinguish cells from other particulate matter.

We inoculated $\sim 300$ rock and rock-powder samples in test tubes in 12 different growth media at five different temperatures $\left(20^{\circ}-85^{\circ} \mathrm{C}\right)$. After 2 weeks of incubation, we observed cell growth in $<10 \%$ of total cultures. We obtained cells that could grow at near in situ temperature, suggesting successful enrichment of indigenous microbes from the warm, shallow basalt aquifer. Microscopic observations of $4^{\prime}$,6-diamidino2 '-phenylindole-dihydrochloride (DAPI)-stained cells revealed coccoid-shaped cells attached to iron sulfide particles. These particles were part of the growth medium. Curiously, in these enrichments no cells were found in association with basalt particles. Considering the chemical composition of the growth medium, these microorganisms probably grow with the provided substrates as carbon sources and ferrous iron as an electron donor. In other enrichments at room temperature, we found anaerobic mesophilic microbes, likely to be fermenters and/or heterotrophic sulfate reducers. There are three conceivable explanations for the retrieval of mesophilic strains: microbes might be derived from sediment above basement, contaminants imported by drilling fluid, or relics transferred to the basaltic oceanic crust by hydrothermal circulation. Further physiological and phylogenetic characterizations of retrieved microbes will be performed as part of shore-based studies.

PFT analyses were completed to evaluate potential for microbiological contamination and the efficacy of cleaning and heating techniques for removing PFT. PFT removal by flame-heating and washing was highly effective for sample exteriors, and little or no PFT was detected in solid rock interiors.

Parts of whole-round basalt cores were run through the multisensor track (MST) prior to splitting. Magnetic susceptibility ranged from 0 to $\sim 4000 \times 10^{-6} \mathrm{SI}$, with the highest values corresponding to massive lava flows. Other lithologies (pillow lava and hyaloclastite) generally yielded much lower values.

Moisture and density properties were determined on 83 discrete samples from Hole U1301B. Bulk density values were $1.86-3.03 \mathrm{~g} / \mathrm{cm}^{3}$ (average $=2.75 \pm 0.13 \mathrm{~g} /$ $\mathrm{cm}^{3}$ ). Grain density exhibited a range of $2.23-3.11 \mathrm{~g} /$ $\mathrm{cm}^{3}$ (average $\left.=2.86 \pm 0.09 \mathrm{~g} / \mathrm{cm}^{3}\right)$. The lowest values of both grain and bulk density were made in a highly brecciated hyaloclastite sample, whereas the highest densities come from the boundary between massive and pillow basalt. Porosity values span the range of $1.9 \%-30.3 \%$ (mean $=5.8 \% \pm 3.5 \%)$. Grain density variability decreases with decreasing porosity, as seen in previous studies of upper basement rocks. Similarly, seismic velocity and porosity are inversely correlated, and velocity displays a weak positive correlation with grain density.

Sixty-eight basalt samples were tested for thermal conductivity, yielding values of $1.17-1.84 \mathrm{~W} / \mathrm{m} \cdot \mathrm{K}$ (average $=1.70 \pm 0.10 \mathrm{~W} / \mathrm{m} \cdot \mathrm{K}$ ) over the depth range of 351.2-576.3 mbsf. There is no statistically significant change in thermal conductivity with depth. Values $>1.75 \mathrm{~W} / \mathrm{m} \cdot \mathrm{K}$ consistently came from large, massive samples (length $>6 \mathrm{~cm}$ ), recovered in either massive flows or pillow basalts. The lowest values of 1.17 and $1.37 \mathrm{~W} / \mathrm{m} \cdot \mathrm{K}$ correspond to the two hyaloclastite samples, suggesting that recovery and sampling biases toward unfractured basalt skew the data toward higher values and likely provide an upper bound on the effective thermal conductivity of uppermost basement in this region.

$P$-wave velocities were measured on 106 discrete samples, yielding values of $3.9-5.8 \mathrm{~km} / \mathrm{s}$ (Fig. F10) (average $=5.1 \pm 0.3 \mathrm{~km} / \mathrm{s}$ ). This average value is greater than that estimated at a regional scale based on seismic reflection data but is consistent with shipboard values from Leg 168 . This value is also slightly greater than the $5.0 \mathrm{~km} / \mathrm{s}$ interval velocity determined for 110-160 msb by the VSP experiment. The lowest velocity was measured on a highly vesicular sample recovered from within a massive flow unit. Additional samples recovered from the same lithologic unit include velocities as great as $\sim 5500 \mathrm{~m} / \mathrm{s}$, demonstrating the extent of small-scale heterogeneity. There is no statistically significant overall velocity trend with depth, although $P$-wave velocity may be reduced locally by alteration and fracturing.

Four wireline logging strings were run in Hole U1301B to characterize formation properties at a scale intermediate between hand samples and regional seismic data. The triple combination (triple combo) tool string (natural gamma ray, lithodensity, porosity, and spontaneous potential) penetrated essentially to total depth (TD), yielding excellent data over most of the open hole (350-580 mbsf; 100-320 $\mathrm{msb}$ ). Unfortunately, subsequent logging strings (Formation MicroScanner [FMS]-sonic, borehole televiewer, and VSP) could not penetrate across an obstruction at $410 \mathrm{mbsf}(150 \mathrm{msb})$, limiting data collection to the uppermost part of the cored interval. Data were also collected through casing, but data from this interval are highly attenuated.

Much of the upper $100 \mathrm{~m}$ of open hole is washed out, with the caliper logs open to full scale near 400 mbsf (Fig. F10). The lower $120 \mathrm{~m}$ of the hole is almost entirely in gauge, being only slightly larger in diameter than the 978 inch coring bit. Formation 
bulk density varies from 1.5 to nearly $3.0 \mathrm{~g} / \mathrm{cm}^{3}$, but the lowest apparent values were measured in washed-out zones and should be used cautiously. In the deeper part of Hole U1301B, variations in bulk density are consistent with observations from numerous other basement holes and with physical property measurements (Fig. F10). There are thin (meter scale) intervals of lower density separated by thicker ( $10 \mathrm{~m}$ scale) intervals of higher density, interpreted to comprise more fractured and massive rock, respectively. Near-hole formation resistivity generally increases with depth in the hole, particularly below the upper $100 \mathrm{~m}$. The spontaneous potential log shows several regions where the curve deflects to the higher values, but it is difficult to interpret these signals hydrogeologically because the logs were collected so soon after drilling, while the formation was still thermally disturbed. Collectively, logging data from the triple combo tool string help to define two main regions in basement. The uppermost $100 \mathrm{~m}$ of open hole is enlarged, with highly variable bulk density and very low electrical resistivity. The lower $120 \mathrm{~m}$ of open hole has a diameter close to that of the coring bit, less variable bulk density, and higher electrical resistivity. The boundary between these two zones, at $\sim 460 \mathrm{mbsf}(210 \mathrm{msb})$, is an important one for subsequent packer testing and CORK monitoring, as described later (Fig. F10).

$P$-wave velocities determined with the sonic log in the upper $80 \mathrm{~m}$ of open basement are generally in the range of $4-6 \mathrm{~km} / \mathrm{s}$ and are broadly consistent with physical property measurements (Fig. F10). A VSP run over a depth range of $\sim 360-420$ mbsf (100$160 \mathrm{msb}$ ) indicates an interval velocity in upper basement of $5.0 \mathrm{~km} / \mathrm{s}$ (Fig. F10).

Unfortunately, no data are available at present from the borehole imaging tools (FMS and borehole televiewer). There are apparently problems with the new wireline heave compensator and/or the acceleration module used with the tools; hopefully, postcruise processing will allow useful images to be generated.

Drill string packer experiments were conducted in Holes U1301A and U1301B to assess hydrogeologic properties near the boreholes (Fig. F10). We originally intended to run the packer in "straddle mode" in Hole U1301B, to assess permeabilities within one or more narrow zones, but because of difficulties encountered in passing a gap in the $103 / 4$ inch casing (see "Operations" in the "Site U1301" chapter), we elected to run the packer only in single-element mode.

Inflation of the packer within the open-hole section of Hole U1301A was precluded by poor hole conditions and the large diameter of the hole, which was drilled with a $143 / 4$ inch bit. The packer was posi- tioned at 267 mbsf, $10 \mathrm{~m}$ above the casing shoe. A depth check before testing found an obstruction at $34 \mathrm{msb}$, compared to total drilled depth of 107.5 msb. We assume that the obstruction was incomplete and that the hydraulically tested interval comprises the $92.6 \mathrm{~m}$ section between casing and total drilled depth. After packer inflation, we recorded sealed-hole pressure and then ran a series of five constant-rate injection tests at 15-100 strokes/min (spm). Following each period of injection, the pressure recovery was monitored for a period of the same duration as the respective pumping time.

Pressure records recovered from downhole gauges after these tests will require considerable processing in order to determine formation properties because of the confounding influences of pressure changes induced through density differences between cold ocean water and warm formation fluids and of formation recovery from the disturbance because of drilling. However, a crude estimate of apparent formation permeability suggests a value on the order of $10^{-11}$ to $10^{-10} \mathrm{~m}^{2}$, considerably greater than determined by packer or flow testing within the upper part of basement in Hole 1026B.

A longer series of packer tests was conducted in Hole U1301B, with the packer set at three depths in open hole. The three packer seats were at 472 mbsf (207 $\mathrm{msb}), 442 \mathrm{mbsf}$ (177 msb), and $417 \mathrm{mbsf}$ (152 msb). These test depths allowed us to assess bulk hydrogeologic properties within the lower formation around Hole U1301B and (by difference) conditions within the upper part of the hole. Packer inflation in the open hole also allowed us to test potential CORK packer seats. After setting the packer at each seat, we conducted two to three injection tests at pumping rates of 11-30 spm. As with data from Hole U1301A, considerable effort will be required to separate the influence of pressure differences associated with formation recovery from drilling and pumping of cold ocean water during the tests themselves. Nevertheless, a crude estimate of near-borehole formation permeability suggests values on the order of $10^{-11} \mathrm{~m}^{2}$, possibly with lower values in the deeper part of the hole.

A CORK system was installed in Hole U1301A to monitor a single depth interval including as much as $92 \mathrm{~m}$ of open hole. The large diameter of the borehole (143/4 inches) precluded setting a CORK packer in open hole, so the packer was set near the bottom of the $103 / 4$ inch casing. Slotted $4 \frac{1}{2}$ inch casing was extended below the packer element to protect the OsmoSamplers and temperature loggers.

The CORK in Hole U1301A used an umbilical comprising a single $1 / 2$ inch packer inflation line, six $1 / 4$ inch pressure-monitoring and sampling lines, and 
one $1 / 8$ inch sampling line. The $1 / 4$ inch and $1 / 8$ inch lines were run through the packer and ended in small wire-wrapped screens. Four of the screens attached to $1 / 4$ inch lines were attached to the $4 \frac{1}{2}$ inch casing just below the packer element, and the remaining screens and lines were terminated roughly in the middle of the $4 \frac{1}{2}$ inch slotted casing. As with the Hole 1026B CORK, the pass-through across the $103 / 4$ inch casing seal that was not plumbed to a formation sampling or monitoring line was connected to a three-way valve and manifold for future installation of pressure-monitoring instrumentation at the wellhead. This plumbing will allow monitoring of fluid pressure below the casing seal and above the packer element, to evaluate system integrity. An OsmoSampler was attached to one of the fluid-sampling manifolds at the wellhead for short-term collection of fluids during the initial few weeks of CORK equilibration.

The Hole U1301A instrument string includes four OsmoSampler packages. The uppermost OsmoSampler contains a copper coil for gas sampling. The next OsmoSampler contains minerals to investigate microbiological growth and biological alteration. The third OsmoSampler has Teflon tubing for fluid sampling and rare earth element tracer injection. The final OsmoSampler includes a module for acid injection into the sampling line, to prevent precipitation of metal compounds. There is a single selfcontained temperature logger in each of the OsmoSamplers (3.7 $\mathrm{m}$ apart), and two additional temperature instruments were installed 2.5 and $7.5 \mathrm{~m}$ above the bottom plug. Thus, temperature monitoring in Hole U1301A extends across $\sim 24.2$ m of upper basement.

The CORK borehole observatory installed in Hole U1301B includes monitoring of three intervals. We initially attempted to set a CORK system in Hole U1301B with three casing packers, all set in open hole, but this system was seriously damaged during deployment and we had to modify its design. The final Hole U1301B CORK system included two casing packers set in open hole. The lowermost packer element isolates the deepest $\sim 120 \mathrm{~m}$ of the hole, whereas this and the shallowest packer isolate a $42 \mathrm{~m}$ thick interval above. A third monitored interval includes uppermost basement and the $103 / 4$ inch casing string below the cone but includes only pressure and temperature monitoring. It should be possible to assess the quality of the hydrogeologic seal at the seafloor using the pressure monitoring line and valve into this interval.
The Hole U1301B CORK system used an umbilical containing nine separate lines: a single $1 / 2$ inch packer inflation line, four $1 / 4$ inch pressure-monitoring and sampling lines, and four $1 / 8$ inch sampling lines. There was a separate $1 / 2$ inch Tefzel (Teflon variant) microbiological sampling line run to the deepest monitored zone. Four small intake screens were deployed below each of the packer elements. The bottom of the CORK installation included $35 \mathrm{~m}$ of drill collars and cross-overs below the lower packer, comprising $\sim 10,000 \mathrm{lb}$ of metal. This configuration was selected to provide enough weight to pull the long CORK casing string into the hole. Sampling and monitoring valves at the wellhead were left open on deployments, and three OsmoSamplers were attached to the fluid-sampling manifolds for shortterm collection of fluids during the initial few weeks of CORK equilibration. Two of these were recovered during ROV servicing in September 2004, whereas the third was left installed for the first year of reequilibration. This OsmoSampler will be recovered during servicing by submersible in Summer 2005.

The downhole sensor and sampling string in Hole U1301B included 14 autonomous temperature loggers, six OsmoSampler packages, and three microbiological incubation packages. Temperature monitoring extends from $\sim 1 \mathrm{~m}$ below the top of basement to $263 \mathrm{~m}$ into basement, with typical sensor spacing of 20-25 m. All of the downhole OsmoSamplers and incubators have their intake lines extending beyond the bottom of the CORK casing system, in open hole. The uppermost OsmoSampler contains a copper coil for gas sampling. The next OsmoSampler contains minerals to investigate microbiological growth and biological alteration and flow cell. The third OsmoSampler has Teflon tubing for fluid sampling and additional incubation substrate. The fourth OsmoSampler includes a module for acid injection into the sampling line, to prevent precipitation of metal compounds. The fifth OsmoSampler is injecting rare earth element tracers, and the final OsmoSampler module is configured for acid addition.

After deployment of the submersible/ROV platform, we "reentered" the cone through a hole in the landing platform and pumped a plug of bentonite followed immediately by cement, in an effort to seal the annulus between 103/4 inch and 16 inch casing strings. Final operations around Hole U1301B included fishing one remaining piece of CORK casing from the initial deployment that was sticking vertically from the seafloor. We conducted a camera sur- 
vey of the area around Holes U1301A and U1301B and found no other items on the seafloor that might pose a hazard for future operations at the site.

\section{References}

Alt, J.C., 1995. Subseafloor processes in mid-ocean ridge hydrothermal systems. In Humphris, S.E., Zierenberg, R., Mullineaux, L., and Thomson, R. (Eds.), Seafloor Hydrothermal Systems: Physical, Chemical, Biological and Geological Interactions within Hydrothermal Systems. Geophys. Monogr., 91:85-114.

Alt, J.C., and Teagle, D.A.H., 1999. The uptake of carbon during alteration of ocean crust. Geochim. Cosmochim. Acta, 63:1527-1535. doi:10.1016/S00167037(99)00123-4

Alt, J.C., and Teagle, D.A.H., 2003. Hydrothermal alteration of upper oceanic crust formed at a fast-spreading ridge: mineral, chemical, and isotopic evidence from ODP Site 801. Chem. Geol., 201:191-211. doi:10.1016/ S0009-2541(03)00201-8

Altman, S.J., Meigs, L.C., Jones, T.L., and McKenna, S.A., 2002. Controls of mass recovery rates in single-well injection-withdrawal tracer tests with a single-porosity, heterogeneous conceptualization. Water Resour. Res., 38:1125. doi:10.1029/2000WR000182

Bach, W., and Edwards, K.J., 2003. Iron and sulfide oxidation within the basaltic ocean crust: implications for chemolithoautotrophic microbial biomass production. Geochim. Cosmochim. Acta, 67(20):3871-3887. doi:10.1016/S0016-7037(03)00304-1

Barker, J.A., 1988. A generalized radial flow model for hydraulic tests in fractured rock, Water Resour. Res., 24:1796-1804.

Becker, K., and Davis, E.E., 2003. New evidence for age variation and scale effects of permeabilities of young oceanic crust from borehole thermal and pressure measurements. Earth. Planet. Sci. Lett., 210(3-4):499-508. doi:10.1016/S0012-821X(03)00160-2

Becker, K., and Davis, E., 2004. In situ determinations of the permeability of the igneous oceanic crust. In Davis, E.E., and Elderfield, H. (Eds.), Hydrogeology of the Oceanic Lithosphere: Cambridge, UK (Cambridge Univ. Press), 189-224.

Becker, K., and Fisher, A.T., 2000. Permeability of upper oceanic basement on the eastern flank of the Juan de Fuca Ridge determined with drill-string packer experiments. J. Geophys. Res., 105:897-912. doi:10.1029/ 1999JB900250

Becker, M.W., and Shapiro, A.M., 2000. Tracer transport in fractured crystalline rock: evidence of nondiffusive breakthrough tailing. Water Resour. Res., 36:1677-1686. doi:10.1029/2000WR900080

Becker, N.C., Wheat, C.G., Mottl, M.J., Karsten, J.L., and Davis, E.E., 2000. A geological and geophysical investigation of Baby Bare, locus of a ridge flank hydrothermal system in the Cascadia Basin. J. Geophys. Res., 105:23557-23568. doi:10.1029/2000JB900204
Bethke, C.M., and Johnson, T.M., 2002. Paradox of groundwater age. Geology, 30:107-110. doi:10.1130/ 0091-7613(2002)030<0107:POGA>2.0.CO;2

Buatier, M.D., Monnin, C., Früh-Green, G.L., and Karpoff, A.-M., 2001. Fluid-sediment interactions related to hydrothermal circulation in the eastern flank of the Juan de Fuca Ridge. Chem. Geol., 175:343-360. doi:10.1016/S0009-2541(00)00327-2

Butler, J.J., Jr., and Healy, J.M., 1998. Relationship between pumping-test and slug-test parameters: scale effect or artifact? Ground Water, 36:305-313.

Clauser, C., 1992. Permeability of crystalline rocks. Eos, Trans. Am. Geophys. Union, 73:233, 237-238.

Clemo, T., and Smith, L., 1997. A hierarchical model for solute transport in fractured media. Water Resour. Res., 33(8):1763-1783. doi:10.1029/97WR01005

Cowen, J.P., Giovannoni, S.J., Kenig, F., Johnson, H.P., Butterfield, D., Rappé, M.S., Hutnak, M., and Lam, P., 2003. Fluids from aging ocean crust that support microbial life. Science, 299:120-123. doi:10.1126/ science. 1075653

Davis, E.E., and Becker, K., 2002. Observations of naturalstate fluid pressures and temperatures in young oceanic crust and inferences regarding hydrothermal circulation. Earth. Planet. Sci. Lett., 204:231-248. doi:10.1016/ S0012-821X(02)00982-2

Davis, E.E., and Becker, K., 2004. Observations of temperature and pressure: constraints on ocean crustal hydrologic state, properties, and flow. In Davis, E.E., and Elderfield, H. (Eds.), Hydrogeology of the Oceanic Lithosphere: Cambridge, UK (Cambridge Univ. Press), 225271.

Davis, E.E., Chapman, D.S., and Forster, C.B., 1996. Observations concerning the vigor of hydrothermal circulation in young oceanic crust. J. Geophys. Res., 101:29272942. doi:10.1029/95JB02997

Davis, E.E., Chapman, D.S., Forster, C.B., and Villinger, H., 1989. Heat-flow variations correlated with buried basement topography on the Juan de Fuca Ridge flank. Nature (London, U. K.), 342:533-537. doi:10.1038/ 342533a0

Davis, E.E., Chapman, D.S., Mottl, M.J., Bentkowski, W.J., Dadey, K., Forster, C., Harris, R., Nagihara, S., Rohr, K., Wheat, G., and Whiticar, M., 1992. FlankFlux: an experiment to study the nature of hydrothermal circulation in young oceanic crust. Can. J. Earth Sci., 29:925-952.

Davis, E.E., Chapman, D.S., Villinger, H., Robinson, S., Grigel, J., Rosenberger, A., and Pribnow, D., 1997a. Seafloor heat flow on the eastern flank of the Juan de Fuca Ridge: data from "FlankFlux" studies through 1995. In Davis, E.E., Fisher, A.T., Firth, J.V., et al., Proc. ODP, Init. Repts., 168: College Station, TX (Ocean Drilling Program), 23-33.

Davis, E.E., Chapman, D.S., Wang, K., Villinger, H., Fisher, A.T., Robinson, S.W., Grigel, J., Pribnow, D., Stein, J., and Becker, K., 1999. Regional heat-flow variations across the sedimented Juan de Fuca Ridge eastern flank: constraints on lithospheric cooling and lateral hydro- 
thermal heat transport. J. Geophys. Res., 104:1767517688. doi:10.1029/1999JB900124

Davis, E.E., and Currie, R.G., 1993. Geophysical observations of the northern Juan de Fuca Ridge system: lessons in sea-floor spreading. Can. J. Earth Sci., 30:278-300.

Davis, E.E., Fisher, A.T., Firth, J.V., et al., 1997. Proc. ODP, Init. Repts., 168: College Station, TX (Ocean Drilling Program).

Davis, E.E., Wang, K., Becker, K., and Thomson, R.E., 2000. Formation-scale hydraulic and mechanical properties of oceanic crust inferred from pore pressure response to periodic seafloor loading. J. Geophys. Res., 105:1342313435. doi:10.1029/2000JB900084

Davis, E.E., Wang, K., He, J., Chapman, D.S., Villinger, H., and Rosenberger, A., 1997b. An unequivocal case for high Nusselt number hydrothermal convection in sediment-buried igneous oceanic crust. Earth Planet. Sci. Lett., 146(1-2):137-150. doi:10.1016/S0012821X(96)00212-9

Davis, E.E., Wang, W., Thomson, R.E., Becker, K., and Cassidy, J.F., 2001. An episode of seafloor spreading and associated plate deformation inferred from crustal fluid pressure transients. J. Geophys. Res., 106:21953-21963. doi:10.1029/2000JB000040

Detrick, R.S., Toomey, D.R., and Collins, J.A., 1998. Threedimensional upper crustal heterogeneity and anisotropy around Hole 504B from seismic tomography. J. Geophys. Res., 103(12):30485-30504. doi:10.1029/ 98JB02409

D’Hondt, S.L., Jørgensen, B.B., Miller, D.J., et al., 2003. Proc. ODP, Init. Repts., 201 [CD-ROM]. Available from: Ocean Drilling Program, Texas A\&M University, College Station TX 77845-9547, USA.

Edwards, K.J., Bach, W., and Rogers, D., 2003. Geomicrobiology of the ocean crust: a role for chemoautotrophic Fe-bacteria. Biol. Bull., 204:180-185.

Edwards, K.J., Rogers, D., Bach, W., and McCollum, T.M., 2002. A role for psychrophilic, rock-altering, chemolithoautotrophic Fe oxidizing bacteria in ocean crust weathering. Eos, Trans. Am. Geophys. Union, 83 (Suppl.):B22E-07. (Abstract)

Elderfield, H., and Schultz, A., 1996. Mid-ocean ridge hydrothermal fluxes and the chemical composition of the ocean. Annu. Rev. Earth Planet. Sci., 24:191-224. doi:10.1146/annurev.earth.24.1.191

Elderfield, H., Wheat, C.G., Mottl, M.J., Monnin, C., and Spiro, B., 1999. Fluid and geochemical transport through oceanic crust: a transect across the eastern flank of the Juan de Fuca Ridge. Earth Planet. Sci. Lett., 172:151-165. doi:10.1016/S0012-821X(99)00191-0

Fisher, A.T., 1998. Permeability within basaltic oceanic crust. Rev. Geophys., 36:143-182. doi:10.1029/ 97RG02916

Fisher, A.T., 2004. Rates and patterns of fluid circulation. In Davis, E.E., and Elderfield, H. (Eds.), Hydrogeology of the Oceanic Lithosphere: Cambridge, UK (Cambridge Univ. Press), 339-377.

Fisher, A.T., 2005. Marine hydrogeology: recent accomplishments and future opportunities. Hydro. J., 13(1). doi:10.1007/s10040-004-0400-y
Fisher, A.T., and Becker, K., 1995. Correlation between seafloor heat flow and basement relief: observational and numerical examples and implications for upper crustal permeability. J. Geophys. Res., 100:12641-12657. doi:10.1029/95JB00315

Fisher, A.T., and Becker, K., 2000. Channelized fluid flow in oceanic crust reconciles heat-flow and permeability data. Nature (London, U. K.), 403:71-74. doi:10.1038/ 47463

Fisher, A.T., Becker, K., and Davis, E.E., 1997. The permeability of young oceanic crust east of Juan de Fuca Ridge determined using borehole thermal measurements. Geophys. Res. Lett., 24(11):1311-1314. doi:10.1029/ 97GL01286

Fisher, A.T., Becker, K., and Narasimhan, T.N., 1994. Offaxis hydrothermal circulation: parametric tests of a refined model of processes at Deep Sea Drilling Project/ Ocean Drilling Program Site 504. J. Geophys. Res., 99(2):3097-3121. doi:10.1029/93JB02741

Fisher, A.T., Davis, E.E., Hutnak, M., Spiess, V., Zühlsdorff, L., Cherkaoui, A., Christiansen, L., Edwards, K.M., Macdonald, R., Villinger, H., Mottl, M.J., Wheat, C.G., and Becker, K., 2003. Hydrothermal recharge and discharge across $50 \mathrm{~km}$ guided by seamounts on a young ridge flank. Nature (London, U. K.), 421:618-621. doi:10.1038/nature01352

Fisher, A.T., Urabe, T., Klaus, A., and the Expedition 301 Project Team, 2004. Juan de Fuca Hydrogeology-The hydrogeologic architecture of basaltic oceanic crust: compartmentalization, anisotropy, microbiology, and crustal-scale properties on the eastern flank of Juan de Fuca Ridge, eastern Pacific Ocean. IODP Sci. Prosp., 301. doi:10.2204/iodp.sp.301.2004

Fisk, M.R., Giovannoni, S.J., and Thorseth, I.H., 1998. Alteration of oceanic volcanic glass: textural evidence of microbial activity. Science, 281:978-980. doi:10.1126/ science.281.5379.978

Fisk, M.R., Thorseth, I.H., Urbach, E., and Giovannoni, S.J., 2000. Investigation of microorganisms and DNA from subsurface thermal water and rock from the east flank of Juan de Fuca Ridge. In Fisher, A., Davis, E.E., and Escutia, C. (Eds.), Proc. ODP, Sci. Results, 168: College Station, TX (Ocean Drilling Program), 167-174.

Fouquet, Y., Zierenberg, R.A., Miller, D.J., et al., 1998. Proc. ODP, Init. Repts., 169: College Station, TX (Ocean Drilling Program).

Furnes, H., and Staudigel, H., 1999. Biological mediation in ocean crust alteration: how deep is the deep biosphere? Earth Planet. Sci. Lett., 166:97-103. doi:10.1016/S0012-821X(99)00005-9

Gelhar, L.W., Welty, C., and Rehfeldt, K.R., 1992. A critical review of data on field-scale dispersion in aquifers. Water Resour. Res., 28(7):1955-1974. doi:10.1029/ 92WR00607

Giambalvo, E.R., Fisher, A.T., Martin, J.T., Darty, L., and Lowell, R.P., 2000. Origin of elevated sediment permeability in a hydrothermal seepage zone, eastern flank of the Juan de Fuca Ridge, and implications for transport 
of fluid and heat. J. Geophys. Res.,105:913-928. doi:10.1029/1999JB900360

Giorgetti, G. Marescotti, P., Cabella, R., and Lucchetti, G., 2001. Clay mineral mixtures as alteration products in pillow basalts from the eastern flank of Juan de Fuca Ridge: a TEM-AEM Study. Clay Mineral., 36(1):75-91.

House, C.H., Cragg, B.A., Teske, A., and the Leg 201 Scientific Party, 2003. Drilling contamination tests during ODP Leg 201 using chemical and particulate tracers. In D’Hondt, S.L., Jørgensen, B.B., Miller, D.J., et al., Proc. ODP, Init. Repts., 201, 1-19 [CD-ROM]. Available from: Ocean Drilling Program, Texas A\&M University, College Station TX 77845-9547, USA.

Hunter, A.G., Kempton, P.D., and Greenwood, P., 1999. Low-temperature fluid-rock interaction: an isotopic and mineralogical perspective of upper crustal evolution, eastern flank of the Juan de Fuca Ridge (JdFR), ODP Leg 168. Chem. Geol., 155(1-2):3-28. doi:10.1016/S00092541(98)00138-7

Jarrard, R.D., Abrams, L.J., Pockalny, R., and Larson, R.L., and Hirono, T., 2003. Physical properties of upper oceanic crust: Ocean Drilling Program Hole 801C and the waning of hydrothermal circulation. J. Geophys. Res., 108. doi:10.1029/2001JB001727

Johnson, H.P., and Holmes, M.L., 1989. Evolution in plate tectonics: the Juan de Fuca Ridge. In Winterer, E.L., Hussong, D.M., and Decker, R.W. (Eds.), The Geology of North America (Vol. N): The Eastern Pacific Ocean and Hawaii: Boulder (Geol. Soc. Am.), 73-91.

Kappel, E.S., and Ryan, W.B.F., 1986. Volcanic episodicity and a non-steady state rift valley along northeast Pacific spreading centers: evidence from Sea MARC I. J. Geophys. Res., 91:13925-13940.

Larson, R.L., Fisher, A.T., Jarrard, R.D., Becker, K., and Ocean Drilling Program Leg 144 Shipboard Scientific Party, 1993. Highly permeable and layered Jurassic oceanic crust in the western Pacific. Earth Planet. Sci. Lett., 119(1-2):71-83.

Marescotti, P., Vanko, D.A., and Cabella, R., 2000. From oxidizing to reducing alteration: mineralogical variations in pillow basalts from the east flank, Juan de Fuca Ridge. In Fisher, A., Davis, E.E., and Escutia, C. (Eds.), Proc. ODP, Sci. Results, 168: College Station, TX (Ocean Drilling Program), 119-136.

Moench, A.F., 1984. Double-porosity models for a fissured groundwater reservoir with fracture skin. Water Resour. Res., 7:831-846.

Monnin, C., Wheat, C.G., Dupre, B., Elderfield, H., and Mottl, M.M., 2001. Barium geochemistry in sediment pore waters and formation waters of the oceanic crust on the eastern flank of the Juan de Fuca Ridge (ODP Leg 168). Geochem. Geophys. Geosyst., 2. doi:10.1029/ 2000GC000073

Moore, J.C., Klaus, A., et al., 1998. Proc. ODP, Init. Repts., 171A: College Station, TX (Ocean Drilling Program).

Mottl, M.J., and Wheat, C.G., 1994. Hydrothermal circulation through mid-ocean ridge flanks: fluxes of heat and magnesium. Geochim. Cosmochim. Acta, 58:2225-2238. doi:10.1016/0016-7037(94)90007-8
Mottl, M.J., Wheat, C.G., Baker, E., Becker, N., Davis, E., Feely, R., Grehan, A., Kadko, D., Lilley, M., Massoth, G., Moyer, C., and Sansone, F., 1998. Warm springs discovered on 3.5 Ma oceanic crust, eastern flank of the Juan de Fuca Ridge. Geology, 26:51-54. doi:10.1130/00917613(1998)026<0051:WSDOMO>2.3.CO;2

Neuman, S.P., 1990. Universal scaling of hydraulic conductivities and dispersivities in geologic media. Water Resour. Res., 26:1749-1758. doi:10.1029/90WR00596

Neuman, S.P., and Di Federico, V., 2003. Multifaceted nature of hydrogeologic scaling and its interpretation. Rev. Geophys., 41. doi:10.1029/2003RG000130

Novakowski, K.S., 1992. The analysis of tracer experiments conducted in divergent radial flow fields. Water Resour. Res., 28:439-447. doi:10.1029/92WR01722

Novakowski, K.S., Lapcevic, P.A., and Voralek, J.W., 1998. A note on a method for measuring the transport properties of a formation using a single well. Water Resour. Res., 34:1351-1356. doi:10.1029/98WR00292

Parkes, R.J., Cragg, B.A., Bale, S.J., Getliff, J.M., Goodman, K., Rochelle, P.A., Fry, J.C., Weightman, A.J., and Harvey, S.M., 1994. Deep bacterial biosphere in Pacific Ocean sediments. Nature (London, U. K.), 371:410-413. doi:10.1038/371410a0

Parsons, B., and Sclater, J.G., 1977. An analysis of the variation of ocean floor bathymetry and heat flow with age. J. Geophys. Res., 82:803-827.

Pribnow, D.F.C., Davis, E.E., and Fisher, A.T., 2000. Borehole heat flow along the eastern flank of the Juan de Fuca Ridge, including effects of anisotropy and temperature dependence of sediment thermal conductivity. $J$. Geophys. Res., 105:13449-13456. doi:10.1029/ 2000JB900005

Renshaw, C.E., 1998. Sample bias and the scaling of hydraulic conductivity in fractured rock. Geophys. Res. Lett., 25:121-124. doi:10.1029/97GL03400

Reysenbach, A.-L., and Shock, E.L., 2002. Merging genomes with geochemistry in hydrothermal ecosystems. Science, 296:1077-1082. doi:10.1126/ science.1072483

Rohr, K., 1994. Inverse of seismic velocities in upper oceanic crust and hydrothermal circulation in the Juan de Fuca plate. Geophys. Res. Lett., 21(19):2163-2166. doi:10.1029/94GL01913

Rosenberg, N., Fisher, A., and Stein, J., 2000. Large-scale lateral heat and fluid transport in the seafloor: revisiting the well-mixed aquifer model. Earth. Planet. Sci. Lett., 182:93-101. doi:10.1016/S0012-821X(00)00235-1

Rosenberger, A., Davis, E.E., and Villinger, H., 2000. Data report: Hydrocell-95 and -96 single-channel seismic data on the eastern Juan de Fuca Ridge flank. In Fisher, A., Davis, E.E., and Escutia, C. (Eds.), Proc. ODP, Sci. Results, 168: College Station, TX (Ocean Drilling Program), 919.

Rovey, C.W.I., and Cherkauer, D.S., 1995. Scale dependency of hydraulic conductivity measurements. Ground Water, 33:769-780.

Rudnicki, M.D., Elderfield, H., and Mottl, M.J., 2001. Pore fluid advection and reaction in sediments of the eastern 
flank, Juan de Fuca Ridge, $48^{\circ}$ N. Earth Planet. Sci. Lett., 187:173-189. doi:10.1016/S0012-821X(01)00287-4

Sanford, W.E., 1997. Correcting for diffusion in carbon-14 dating of ground water. Ground Water, 35:357-361.

Schulze-Makuch, D., and Cherkauer, D.S., 1997. Method developed for extrapolating scale behavior. Eos, Trans. Am. Geophys. Union, 78:3. (Abstract)

Shapiro, A.M., 2001. Effective matrix diffusion in kilometer-scale transport in fractured crystalline rock. Water Resour. Res., 37(3):507-522. doi:10.1029/ 2000WR900301

Shapiro, A.M., and Hsieh, P.A., 1998. How good are estimates of transmissivity from slug tests in fractured rocks? Ground Water, 36:37-48.

Shipboard Scientific Party, 1997. Rough basement transect (Sites 1026 and 1027). In Davis, E.E., Fisher, A.T., Firth, J.V., et al., Proc. ODP, Init. Repts., 168: College Station, TX (Ocean Drilling Program), 101-160.

Smith, D.C., Spivack, A.J., Fisk, M.R., Haveman, S.A., and Staudigel, H., 2000. Tracer-based estimates of drillinginduced microbial contamination of deep sea crust. Geomicrobiol. J., 17:207-219.

Smith, W.H.F., and Sandwell, D.T., 1997. Global seafloor topography from satellite altimetry and ship depth soundings. Science, 277:1956-1962. doi:10.1126/ science.277.5334.1956

Spinelli, G.A., and Fisher, A.T., 2004. Hydrothermal circulation within topographically rough basaltic basement on the Juan de Fuca Ridge flank. Geochem., Geophys., Geosyst., 5. doi:10.1029/2003GC000616

Spinelli, G.A., Zühlsdorff, L., Fisher, A.T., Wheat, C.G., Mottl, M., Spiess, V., and Giambalvo, E.R., 2004. Hydrothermal seepage patterns above a buried basement ridge, eastern flank of the Juan de Fuca Ridge. J. Geophys. Res., 109. doi:10.1029/2003JB002476

Stein, J.S., and Fisher, A.T., 2003. Observations and models of lateral hydrothermal circulation on a young ridge flank: numerical evaluation of thermal and chemical constraints. Geochem., Geophys., Geosyst., 4. doi:10.1029/2002GC000415

Stein, C.A., and Stein, S., 1994. Constraints on hydrothermal heat flux through the oceanic lithosphere from global heat flow. J. Geophys. Res., 99:3081-3095. doi:10.1029/93JB02222

Stephen, R.A., 1985. Seismic anisotropy in the upper oceanic crust. J. Geophys. Res., 90:11383-11396.
Tsang, C.F., and Neretnieks, I., 1998. Flow channeling in heterogeneous fractured rocks. Rev. Geophys., 36:275298. doi:10.1029/97RG03319

Underwood, M.B., Hoke, K.D., Fisher, A.T., Davis, E.E., Giambalvo, E., Zühlsdorff, L., and Spinelli, G.A., 2005. Provenance, stratigraphic architecture, and hydrogeologic influence of turbidites on the mid-ocean ridge flank of northwestern Cascadia Basin, Pacific Ocean. J. Sediment. Res., 75(1):149-164. doi:10.2110/jsr.2005.012

Wang, K., He, J., and Davis, E.E., 1997. Influence of basement topography on hydrothermal circulation in sediment-buried igneous oceanic crust. Earth Planet. Sci. Lett., 146:151-164. doi:10.1016/S0012821X(96)00213-0

Wheat, C.G., Elderfield, H., Mottl, M.J., and Monnin, C., 2000. Chemical composition of basement fluids within an oceanic ridge flank: implications for along-strike and across-strike hydrothermal circulation. J. Geophys. Res., 105(6):13437-13448. doi:10.1029/2000JB900070

Wheat, C.G., Jannasch, H.W., Kastner, M., Plant, J.N., and DeCarlo, E.H., 2003. Seawater transport and reaction in upper oceanic basaltic basement: chemical data from continuous monitoring of sealed boreholes in a ridge flank environment. Earth Planet. Sci. Lett., 216:549-564. doi:10.1016/S0012-821X(03)00549-1

Wheat, C.G., and Mottl, M., 2000. Composition of pore and spring waters from Baby Bare: global implications of geochemical fluxes from a ridge flank hydrothermal system. Geochim. Cosmochim. Acta, 64:629-642. doi:10.1016/S0016-7037(99)00347-6

Wheat, C.G., Mottl, M., and Rudnicki, M., 2002. Trace element and REE composition of a low-temperature ridgeflank hydrothermal spring. Geochim. Cosmochim. Acta, 66:3693-3705. doi:10.1016/S0016-7037(02)00894-3

Wheat, C.G., and Mottl, M.G., 1994. Hydrothermal circulation, Juan de Fuca Ridge eastern flank: factors controlling basement water composition. J. Geophys. Res., 99:3067-3080. doi:10.1029/93JB01612

Whitman, W.B., Coleman, D.C., and Wiebe, W.J., 1998. Prokaryotes: the unseen majority. Proc. Nat. Acad. Sci. U.S.A., 95:6578-6583. doi:10.1073/pnas.95.12.6578

Publication: 31 October 2005 MS 301-101 
Figure F1. Regional bathymetric map showing major tectonic features and the locations of IODP Expedition 301 drill sites and the ODP Leg 168 drilling transect. Bathymetry from Smith and Sandwell (1997). FR = First Ridge, SR = Second Ridge, DR = Deep Ridge.

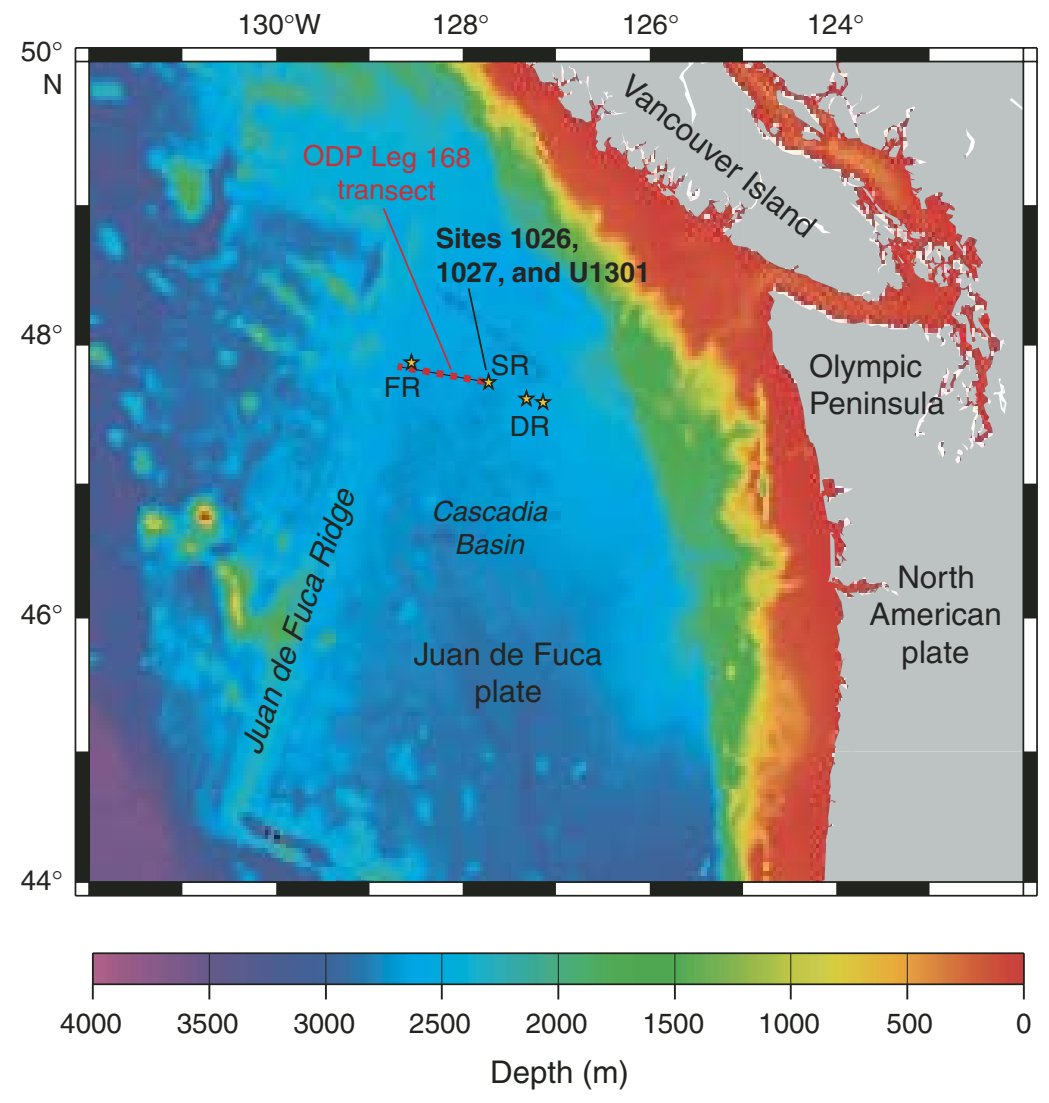


Figure F2. Summary of selected results from Leg 168 and related experiments. A. Interpreted composite cross section from the active spreading center to the west, across the Leg 168 drilling transect, and continuing to the east (Davis, Fisher, Firth, et al., 1997). Vertical lines show locations of Leg 168 boreholes. Triangles at seafloor show locations of reentry cones and CORK observatories installed during Leg 168. CORK systems in Holes 1026B and 1027C were replaced during Expedition 301, and new CORKs were emplaced in Holes U1301A and U1301B, along the same buried basement ridge as Site 1026. B. Summary of thermal data. Solid circles are upper basement temperatures, based on in situ measurements and (in some cases) short extrapolations to basement depths. Open squares are heat flow values determined with Leg 168 temperature and thermal conductivity data, after applying temperature corrections and accounting for thermal conductivity anisotropy (Pribnow et al., 2000). Solid squares show the same values after correction for the effects of rapid sedimentation (Davis et al., 1999). Data from Sites 1030 and 1031 were not sediment-corrected because sediment cover is very thin and because the calculated correction is based on a one-dimensional approximation that is not valid where there are large variations in basement relief below thin sediments. The thin jagged line shows estimated heat flow values across the Leg 168 transect based on seismic and drilling data (Davis et al., 1999), after applying a sedimentation correction. The smooth dotted and dashed curves show lithospheric reference models by Parsons and Sclater (1977) and Stein and Stein (1994), respectively. C. Chemistry of basement fluids, as determined from extrapolation of basal pore fluid gradients to the basement depths and (in the case of Hole 1026B) from direct sampling of formation fluids. Magnesium data show fluid alteration largely as a function of reaction temperature (Davis, Fisher, Firth, et al., 1997; Wheat and Mottl, 1994). ${ }^{14} \mathrm{C}$ data show a consistent progression in apparent age from west to east at the western end of the transect, but samples from Sites 1031 and 1026 are considerably younger than waters to the west (Elderfield et al., 1999).

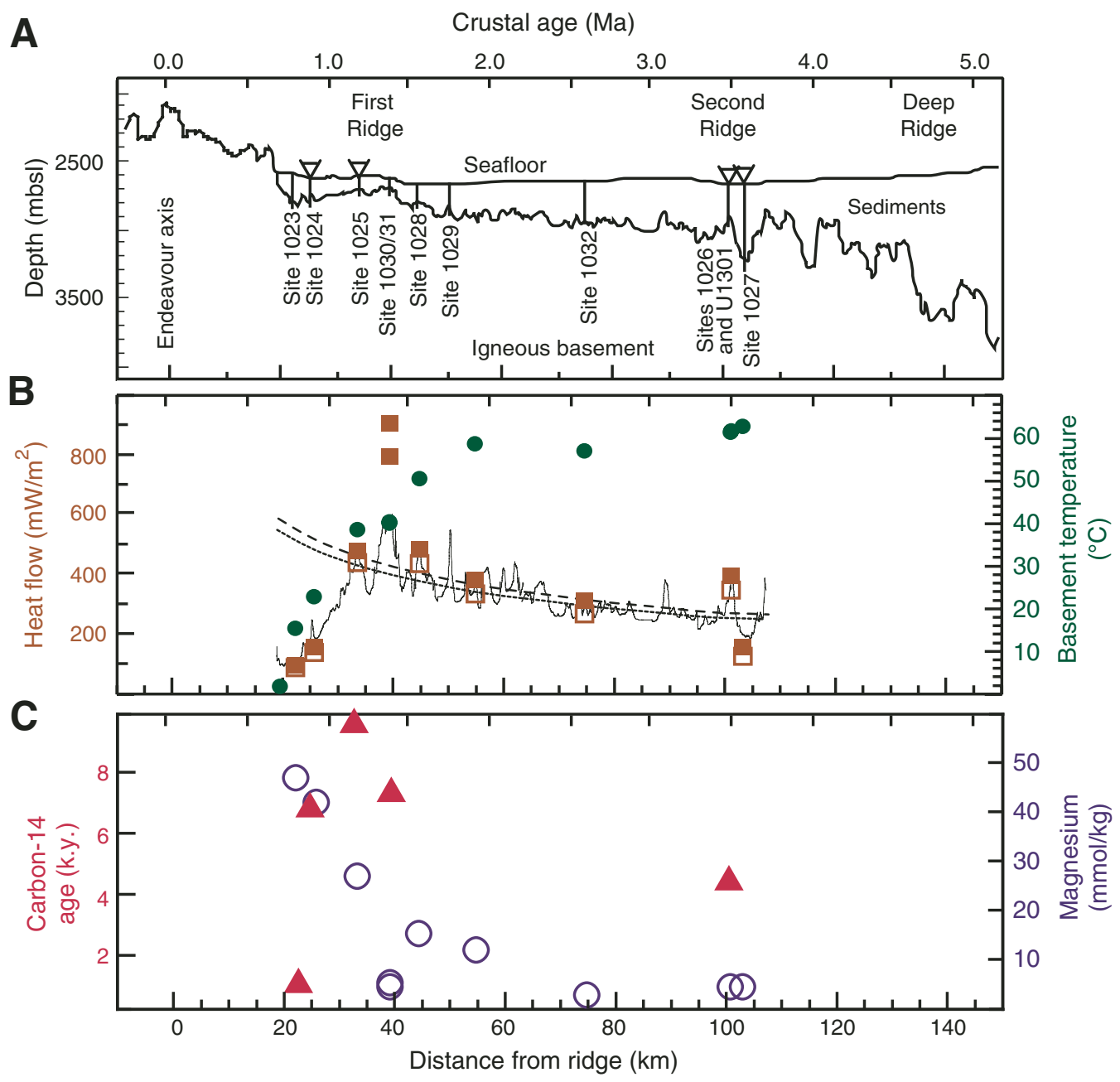


Figure F3. Second Ridge maps. A. Topographic map showing Second Ridge and surrounding region (modified from Fisher et al., 2003). Locations of ODP and IODP holes are shown, as are locations of outcrops that penetrate regionally continuous sediment cover. B. Basement map of Second Ridge drilling area, showing ODP and IODP hole locations (Zühlsdorff et al., this volume). Data are based on bathymetry shown in A and interpretation of $\sim 25$ seismic lines collected during the 2000 Sonne expedition (ImageFlux). Holes at Site SR-2 will be drilled during a subsequent expedition.

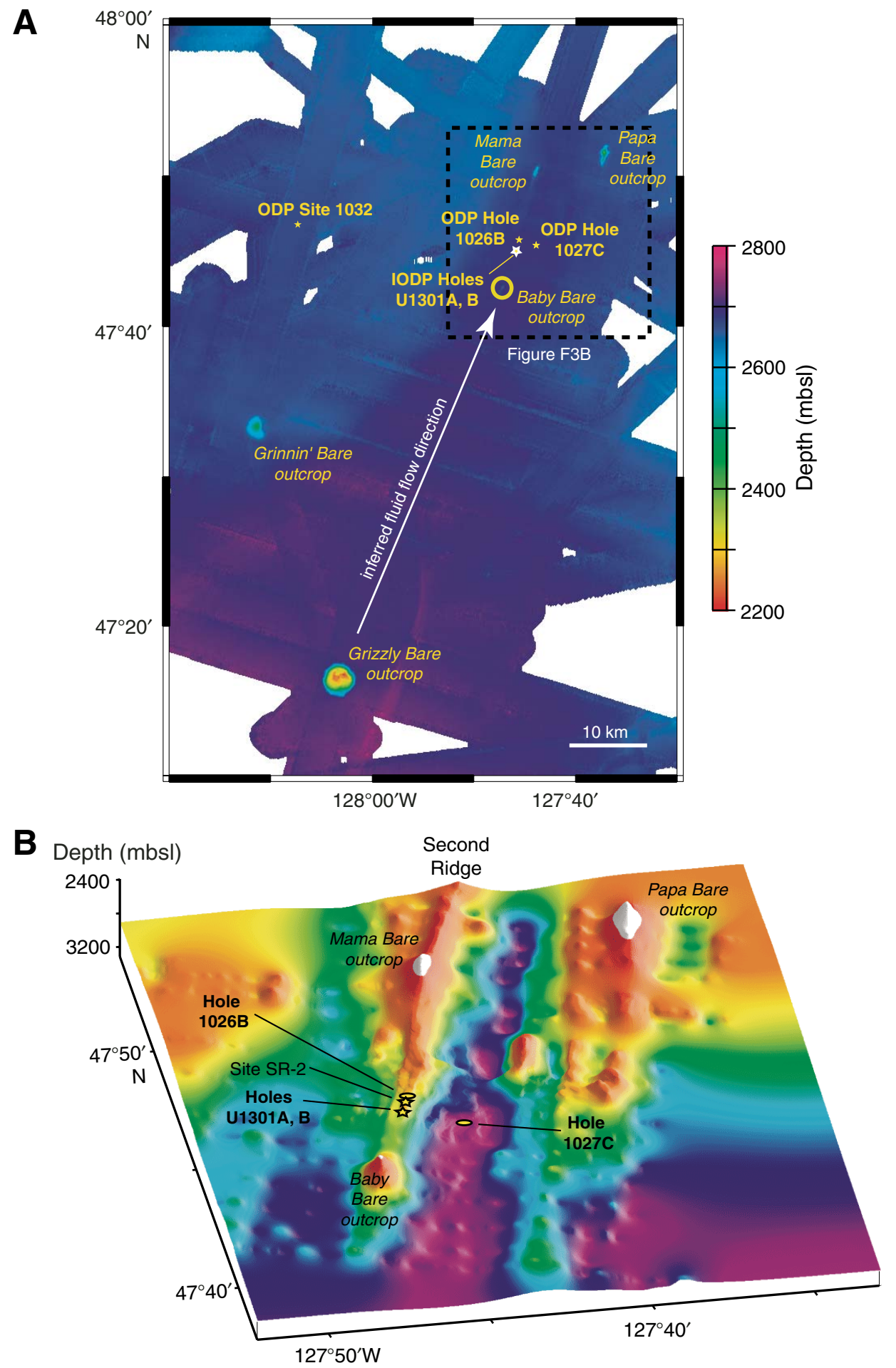


Figure F4. Examples of MCS seismic data from the 2000 ImageFlux survey (Sonne, SO149) showing locations of primary Expedition 301 sites. A. Line GeoB00-446 across the southern part of Site U1301. Vertical lines indicate approximate total depth of Holes U1301A (shallower) and U1301B (deeper). B. Line GeoB00-203 across Sites 1026 and 1027. Vertical lines indicate approximate total depth of both holes. Characteristic basement and sedimentary structures are apparent in both lines. These features are described in the text and in Zühlsdorff et al. (this volume), who also discuss data acquisition and processing.
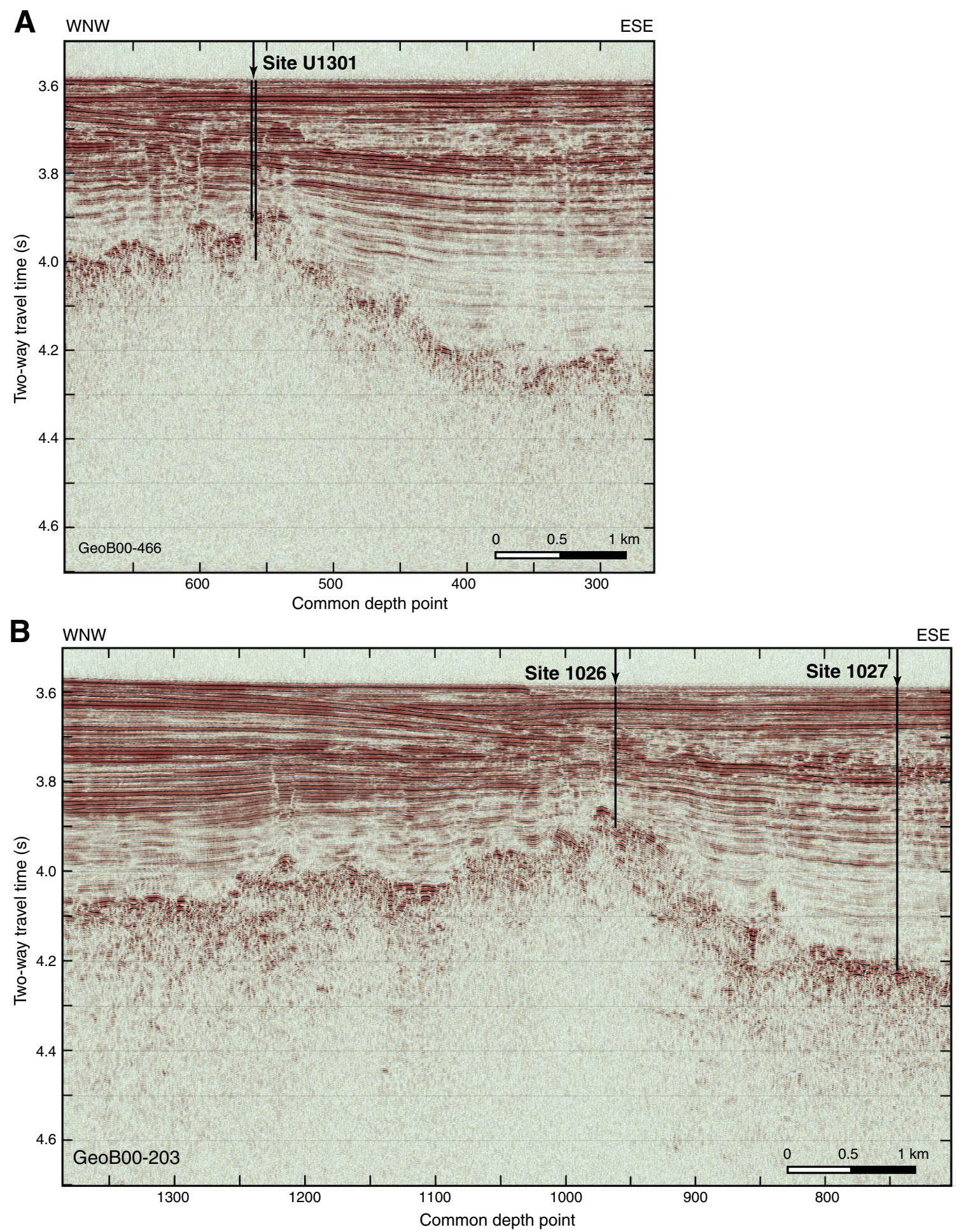
Figure F5. Permeability of upper oceanic crust versus crustal age and measurement scale prior to Expedition 301. A. Permeability versus crustal age. Squares (red) show packer measurements, circles (blue) show results from temperature log (flow meter) experiments. Bars indicate uncertainties in crustal age and estimated bulk permeability. Dashed line shows crude permeability-age trend, with a rapid reduction during the first 4 m.y., followed by a maintenance of bulk permeability of $\sim 10^{-14}$ to $10^{-13} \mathrm{~m}^{2}$ (data compiled from these studies and sources cited therein: Fisher, 1998; Fisher and Becker, 2000; Becker and Davis, 2004). Additional data were collected in 165 Ma seafloor (Larson et al., 1993) but are not shown. Temperature data generally suggest permeabilities somewhat higher than those suggested by packer data. Shaded regions are results of calculations of permeability trends based on consideration of global heat flow data (Fisher and Becker, 2000). Borehole observations are consistent with global heat flow considerations until $\sim 4 \mathrm{Ma}$, and then observations deviate from these predictions. This may occur because flow becomes more focused with age, as smaller pores fill. B. Permeability estimates from boreholes on the eastern flank of the Juan de Fuca Ridge, plotted as a function of measurement scale (solid symbols and blue shaded areas [Becker and Davis, 2003]). Other shaded areas indicate compilations for fractured crystalline rocks (red bands [Clauser, 1992]) and results from tests in fractured sedimentary rocks (green bands [Rovey and Cherkauer, 1995; Schulze-Makuch and Cherkauer, 1997]). Expedition 301 and related experiments will help to elucidate the scaling of crustal permeability over the range indicated with the double-headed arrow, as discussed in the text and in later figures.
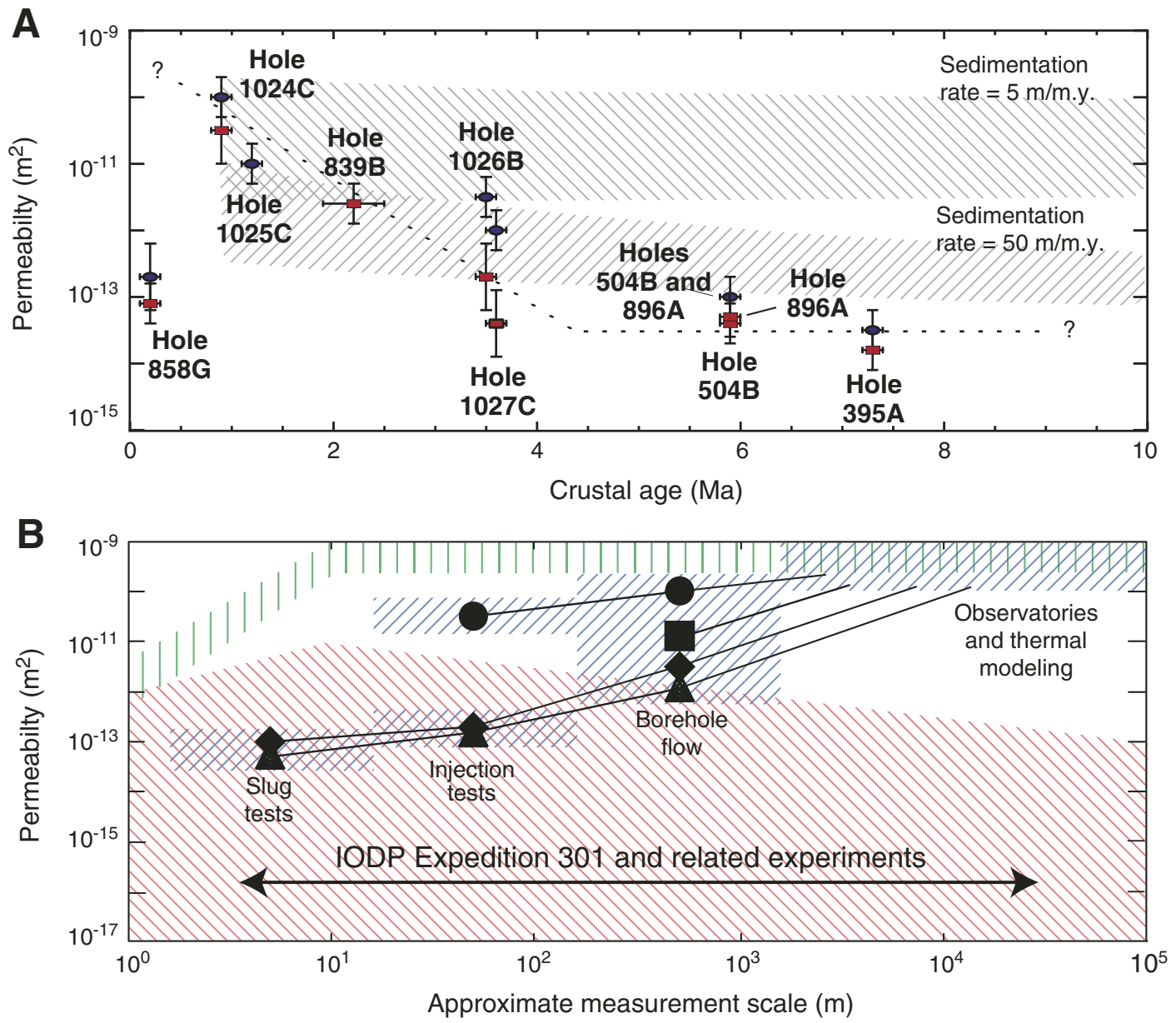
Figure F6. Crustal-scale hydrogeologic testing associated with Expedition 301 and related experiments. A. Map view indicating spatial relations between CORK observatories (colored circles) in Holes 1026B, 1027C, U1301A, U1301B, planned Site SR-2 and nearby basement outcrops (gold bathymetric contours). Inset shows relative locations of holes used for cross-hole experiments. Depth contours in meters. B. Calculated cross-hole responses to pumping and free-flow borehole experiments between holes at Sites SR-2 and 1026, separated by $200 \mathrm{~m} . S=$ storativity, $T=$ transmissivity. C. Calculated cross-hole responses to pumping and free-flow borehole experiments between holes at Sites SR-2 and 1027, separated by $2200 \mathrm{~m}$. Sites SR-2 and U1301 are $800 \mathrm{~m}$ apart, so the anticipated response is intermediate between the examples shown. Assumed formation properties are based on previously completed packer, free-flow, and CORK experiments. Differences in formationscale values of $T$ and $S$ relative to those used would shift the curves as indicated by the arrows in B. Pumping tests in DSDP and ODP were typically only $20 \mathrm{~min}$ long (dotted vertical line); Expedition 301 tests were as long as $2 \mathrm{~h}$. Future tests will begin with $24 \mathrm{~h}$ of pumping (dashed vertical line), and ultimately will last $1-2 \mathrm{y}$ or more through venting of overpressured holes and pumping at the seafloor.

A

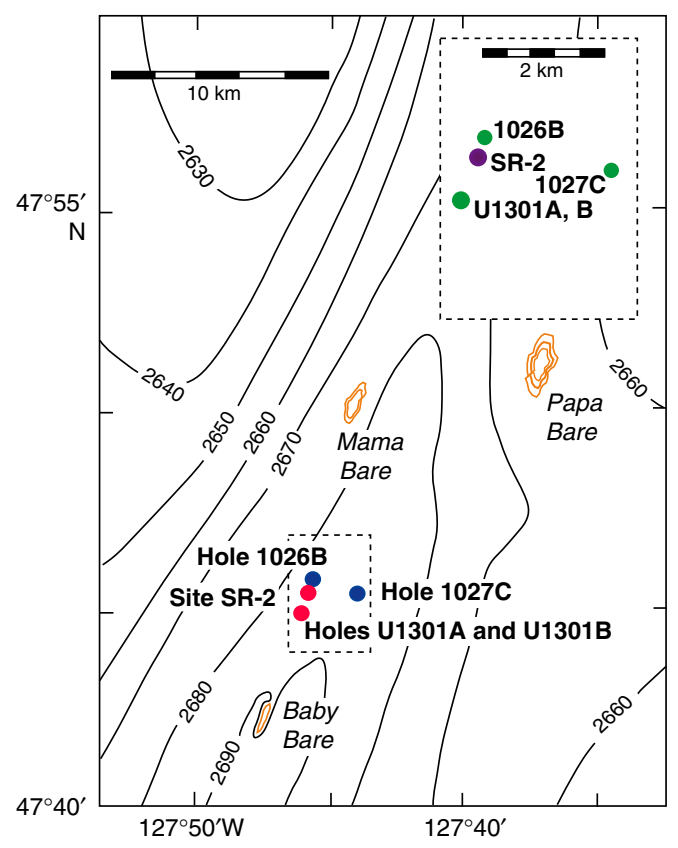

B

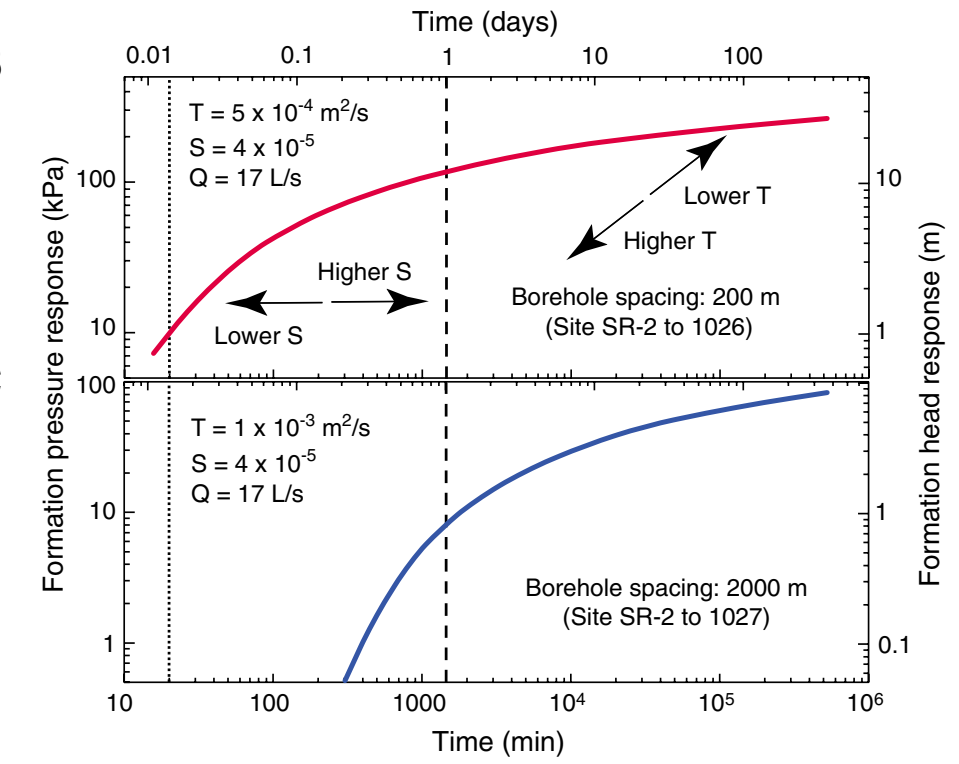


Figure F7. Cell density data from ODP sediment cores. Solid circles are data from ODP Leg 201 (D'Hondt, Jørgensen, Miller, et al., 2003) and dotted region shows 2- $\sigma$ envelope around global compilation of previously censused ODP sites (Parkes et al., 1994). It is not clear whether this trend will be continued into basement, or if populations will be greater or less than projected, particularly within narrow zones that carry most of the hydrothermal flow. Long-term monitoring and sampling within CORK observatories will provide the best opportunity to address this uncertainty.

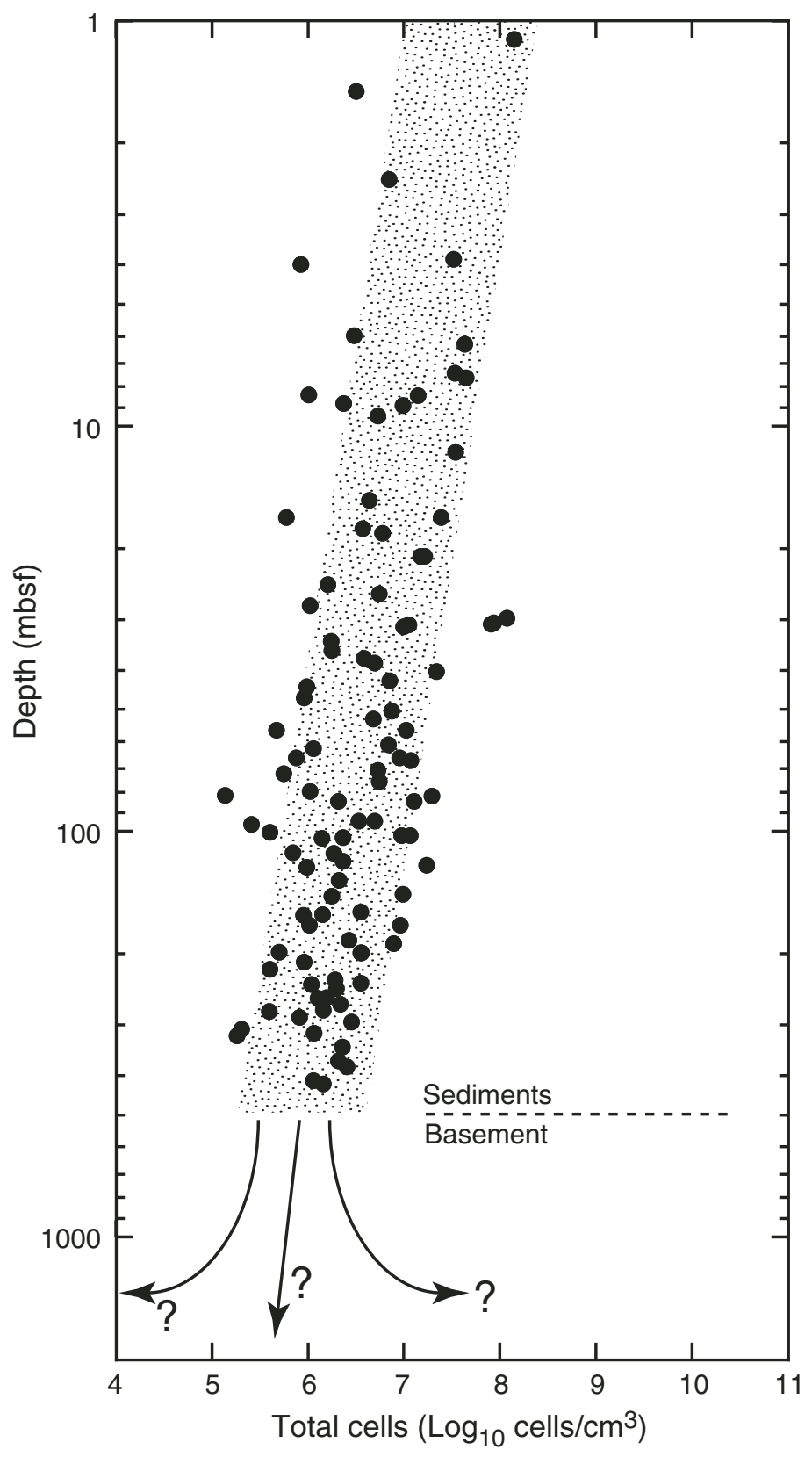


Figure F8. Cartoon illustrating selected features of the three CORK borehole observatory systems installed during Expedition 301. Approximate total depths (TD) listed in meters subbasement (msb) are correct as shown, but drawings are not to scale and do not indicate precise locations of casing, cones, packers, sampling and monitoring lines, or downhole instruments. Hole 1026B was created during Leg 168, whereas Holes U1301A and U1301B were created during Expedition 301. All three CORKs monitor multiple depth intervals. The CORKs in Holes 1026B and U1301A monitor shallowest basement and the zone between the casing packer and the seafloor CORK seal. The CORK in Hole U1301B monitors three basement intervals, with the uppermost interval extending to the seafloor seal. Instruments deployed at depth in all three CORK systems include OsmoSamplers for fluid chemistry, microbiological growth substrate, and autonomous temperature loggers distributed within basement. See Fisher et al. (this volume) and the "Site U1301" and "Site 1026" chapters for additional details regarding CORK configuration and deployment.

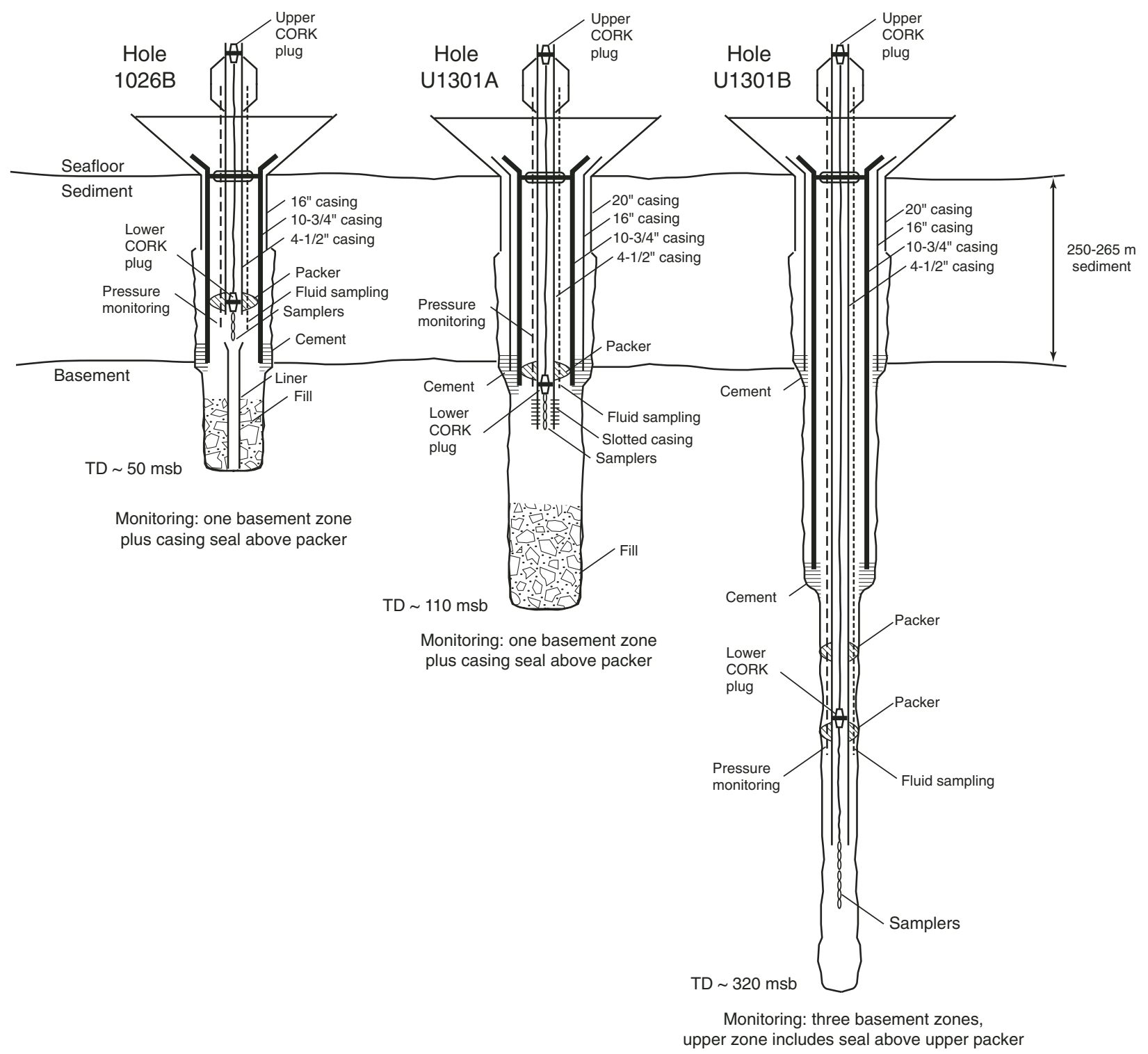


Figure F9. Penetration rates at Site U1301 while drilling with a 143/4 inch tricone bit in preparation for casing. A. Hole U1301A. B. Hole U1301B. Information was derived from recordings of bit depth made at $1 \mathrm{~s}$ intervals by the shipboard rig instrumentation system (RIS). Because motion of the drill string is not monotonically downward (intervals are drilled, reamed, and cleaned, and ship heave and tides also contribute to bit motion), RIS data required hand filtering and editing to determine penetration rates. Gaps in the data occur near pipe joints and as a result of incorrect recordings of bit depth. msb = meters subbasement.

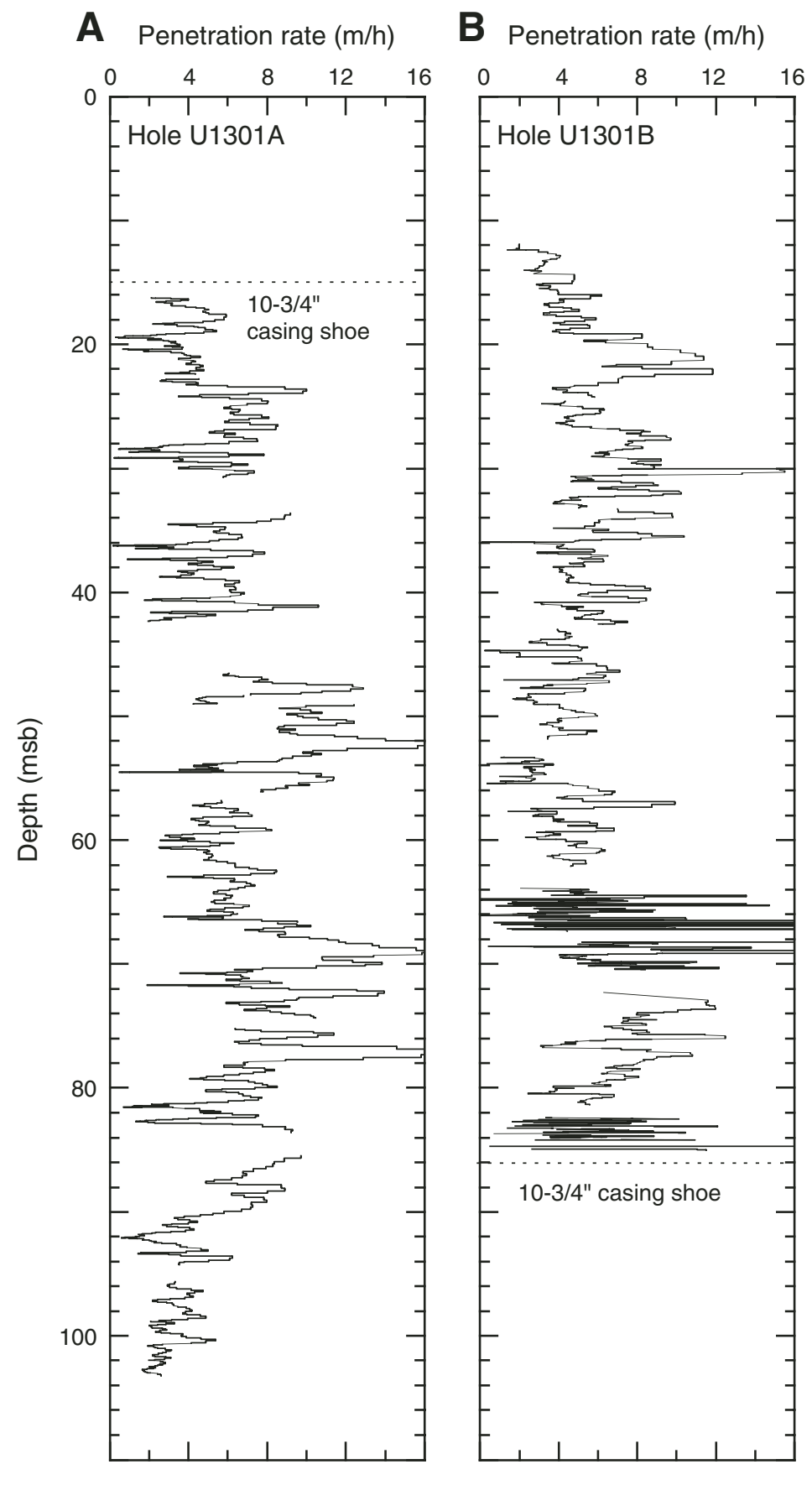

B Penetration rate $(\mathrm{m} / \mathrm{h})$ 
Figure F10. Summary of selected data from basement in Hole U1301B. Columns on the left show depth below seafloor, cored intervals, and recovery. Primary lithologies and lithologic units were defined on the basis of igneous petrology. The next five columns show wireline logging results. The caliper log is from the litho-density tool, and the diameter of the drill bit and the maximum recommended packer inflation diameter (for both drill string and CORK packers) is shown for reference. Wireline bulk density data are compared to measurements of small hand samples. Resistivity data are from the near-borehole $(\sim 10 \mathrm{~cm})$ and medium-penetration $(\sim 30 \mathrm{~cm})$ electrode spacings. The spontaneous potential (SP) log is sometimes used as a hydrogeologic flow indicator, but data were collected in Hole U1301B soon after the end of drilling and casing operations, before the hole had a chance for thermal equilibration, so SP variations may be more influenced by temperature than by fluid flow into or out of the formation. The sonic logging tool did not penetrate a borehole obstruction at $420 \mathrm{mbsf}$, but data collected in the upper part of the hole are in general agreement with both physical property measurements and an interval velocity determined from a vertical seismic profile (thin rectangle). Magnetic inclinations were determined on individual samples. Symbols are defined in the appropriate section of the Site U1301 report. Note change from dominantly positive magnetic inclinations in the upper $100 \mathrm{~m}$ of the hole to mixed positive and negative inclinations in the lower part of the hole. Intervals tested with a drill string packer, and monitored by CORK observatories in Holes U1301A and U1301B, are shown in the last two panels. The primary depth scale (mbsf) is referenced to Hole U1301B, but packer and CORK depths for Hole U1301A are registered to the depth into basement (msb). Finally, the dotted band near 465 mbsf $(210 \mathrm{msb})$ shows an apparent boundary between crustal intervals having distinct properties. (Figure shown on next page.) 


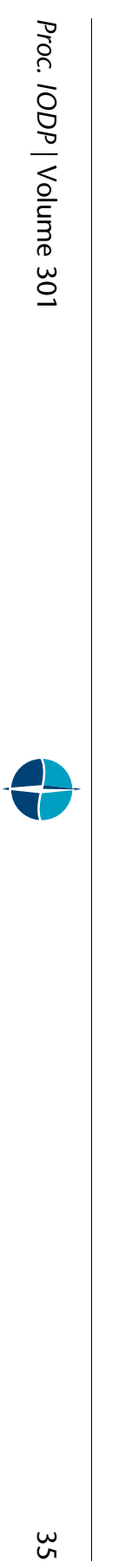

Figure F10 (continued). (Caption shown on previous page.)

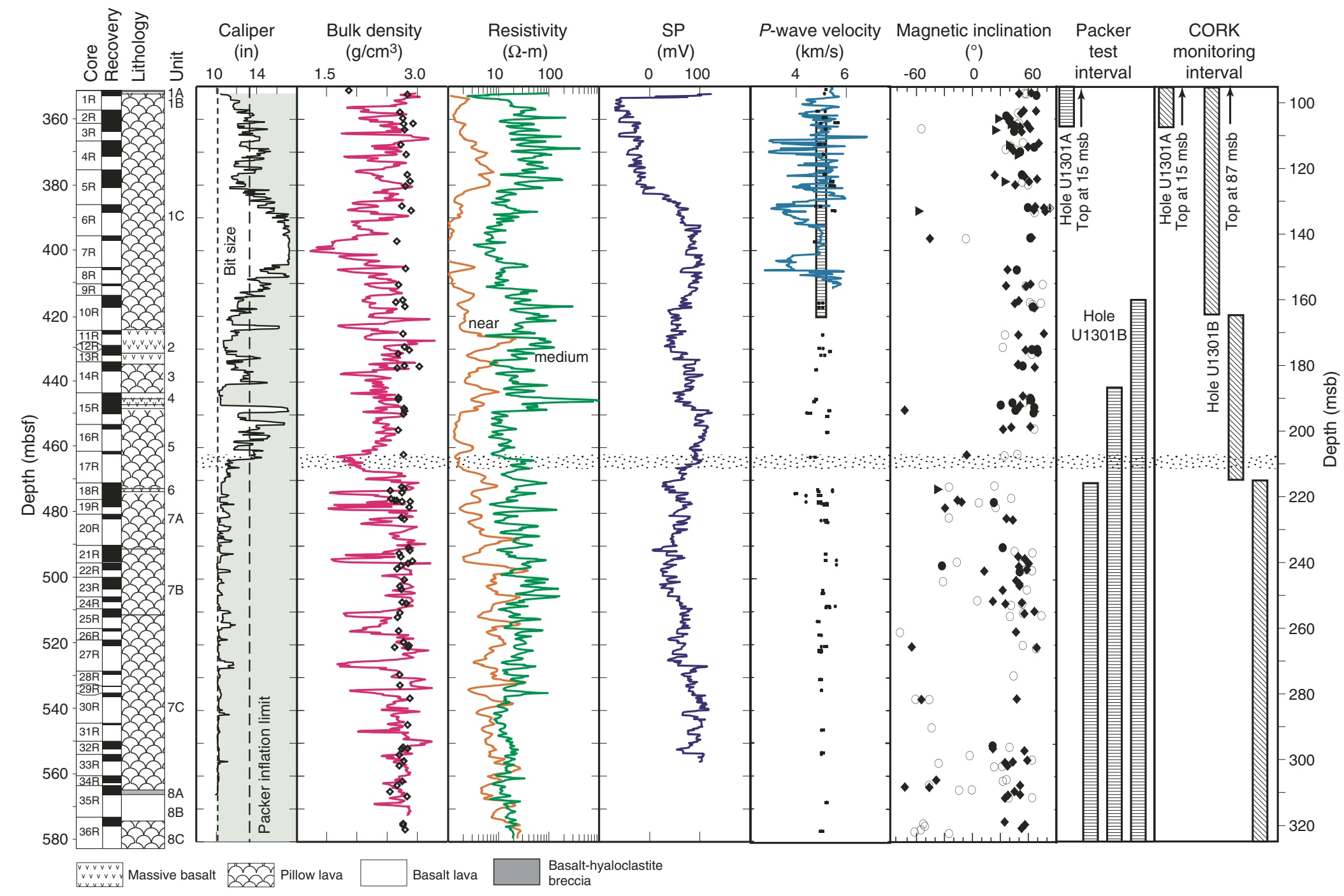


Table T1. Expedition 301 operational steps with start and end times and dates. (See table notes. Continued on next page).

\begin{tabular}{|c|c|c|c|c|c|c|}
\hline \multirow[b]{3}{*}{ Operational task } & \multicolumn{2}{|c|}{ Start } & \multicolumn{2}{|c|}{ End } & & \\
\hline & \multirow{2}{*}{$\begin{array}{l}\text { Date } \\
(2004)\end{array}$} & \multirow{2}{*}{$\begin{array}{l}\text { Local } \\
\text { ship time } \\
\text { (h) }\end{array}$} & \multirow{2}{*}{$\begin{array}{c}\text { Date } \\
(2004)\end{array}$} & \multirow{2}{*}{$\begin{array}{l}\text { Local } \\
\text { ship time } \\
\text { (h) }\end{array}$} & \multicolumn{2}{|c|}{ Task time } \\
\hline & & & & & (h) & (days) \\
\hline End Expedition 301 port call in Astoria, Oregon & & & 27 Jun & 0600 & & \\
\hline Depart Astoria, Oregon, for Site U1301 & 27 Jun & 0600 & 27 Jun & 0830 & 2.50 & 0.1 \\
\hline Cross Columbia River Bar & 27 Jun & 0830 & 27 Jun & 1030 & 2.00 & 0.1 \\
\hline Transit $\sim 172$ nmi to Site U1301 (SR-1A) & 27 Jun & 1030 & 28 Jun & 0315 & 16.75 & 0.7 \\
\hline \multicolumn{7}{|l|}{ Hole U1301A: } \\
\hline Jet-in test & 28 Jun & 0315 & 29 Jun & 0400 & 24.75 & 1.0 \\
\hline Install reentry cone and 20 inch casing & 29 Jun & 0400 & 30 Jun & 0545 & 25.75 & 1.1 \\
\hline Drill 20 inch hole in sediment with underreamer for 16 inch casing & 30 Jun & 0545 & $01 \mathrm{Jul}$ & 1130 & 29.75 & 1.2 \\
\hline Drill 20 inch hole in basement with bicenter bit & $01 \mathrm{Jul}$ & 1130 & $02 \mathrm{Jul}$ & 1345 & 26.25 & 1.1 \\
\hline Install 16 inch casing & $02 \mathrm{Jul}$ & 1345 & $03 \mathrm{Jul}$ & 1230 & 22.75 & 0.9 \\
\hline Drill $143 / 4$ inch hole with tricone bit in basement for $103 / 4$ inch casing & 03 Jul & 1230 & $06 \mathrm{Jul}$ & 0400 & 63.50 & 2.6 \\
\hline $\begin{array}{l}\text { Install } 103 / 4 \text { inch casing } \\
\text { Offset ship } 36 \mathrm{~m} \mathrm{~N} 13^{\circ} \mathrm{E} \text { to Hole U1301B }\end{array}$ & $06 \mathrm{Jul}$ & 0400 & $08 \mathrm{Jul}$ & 0800 & 52.00 & 2.2 \\
\hline \multicolumn{7}{|l|}{ Hole U1301B: } \\
\hline Install reentry cone and 20 inch casing & $08 \mathrm{Jul}$ & 0800 & $09 \mathrm{Jul}$ & 0900 & 25.00 & 1.0 \\
\hline Repair underreamer & $09 \mathrm{Jul}$ & 0900 & $09 \mathrm{Jul}$ & 1645 & 7.75 & 0.3 \\
\hline Drill 20 inch hole $11 \mathrm{~m}$ into basement with $18 \frac{1}{2}$ inch bit and underreamer & $09 \mathrm{Jul}$ & 1645 & $11 \mathrm{Jul}$ & 0600 & 37.25 & 1.6 \\
\hline Install 16 inch casing & $11 \mathrm{Jul}$ & 0600 & $12 \mathrm{Jul}$ & 0130 & 19.50 & 0.8 \\
\hline Drill $143 / 4$ inch hole with tricone bit in basement for $10^{3 / 4}$ inch casing & $12 \mathrm{Jul}$ & 0130 & $14 \mathrm{Jul}$ & 0215 & 48.75 & 2.0 \\
\hline Install $103 / 4$ inch casing; unable to land, pull out of hole & $14 \mathrm{Jul}$ & 0215 & $15 \mathrm{Jul}$ & 0515 & 27.00 & 1.1 \\
\hline Ream hole with $143 / 4$ inch tricone bit & $15 \mathrm{Jul}$ & 0515 & $16 \mathrm{Jul}$ & 0500 & 23.75 & 1.0 \\
\hline Install 103/4 inch casing & $16 \mathrm{Jul}$ & 0500 & $17 \mathrm{Jul}$ & 0045 & 19.75 & 0.8 \\
\hline Equipment transfer by helicopter, $1100 \mathrm{~h}$ on 16 July & & & & & & \\
\hline Transit $0.55 \mathrm{nmi}$ to Site 1026 in DP mode (during pipe trip) & $17 \mathrm{Jul}$ & 0045 & $17 \mathrm{Jul}$ & 0045 & 0.00 & 0.0 \\
\hline \multicolumn{7}{|l|}{ Hole 1026B: } \\
\hline $\mathrm{RIH} /$ Fish aluminum reentry funnel/POOH & $17 \mathrm{Jul}$ & 0045 & $17 \mathrm{Jul}$ & 1200 & 11.25 & 0.5 \\
\hline Transit $0.55 \mathrm{nmi}$ to Site U1301 (during pipe trip) & 17 Jul & 1200 & 17 Jul & 1200 & 0.00 & 0.0 \\
\hline \multicolumn{7}{|l|}{ Hole U1301A: } \\
\hline Drill out cement, check and clean hole to total depth & $17 \mathrm{Jul}$ & 1200 & $18 \mathrm{Jul}$ & 0315 & 15.25 & 0.6 \\
\hline Hydrologic (packer) testing & $18 \mathrm{Jul}$ & 0315 & $19 \mathrm{Jul}$ & 1000 & 30.75 & 1.3 \\
\hline Install CORK and ROV platform & 19 Jul & 1000 & $21 \mathrm{Jul}$ & 0230 & 40.50 & 1.7 \\
\hline Offset ship $36 \mathrm{~m}$ back to Hole U1301B (during pipe trip) & & & & & & \\
\hline \multicolumn{7}{|l|}{ Hole U1301B: } \\
\hline Drill out cement & $21 \mathrm{Jul}$ & 0230 & $21 \mathrm{Jul}$ & 1800 & 15.50 & 0.6 \\
\hline $\mathrm{RCB}$ core to $582.8 \mathrm{mbsf}$ & $21 \mathrm{Jul}$ & 1800 & $31 \mathrm{Jul}$ & 2245 & 244.75 & 10.2 \\
\hline Wireline logging; four runs & $31 \mathrm{Jul}$ & 2245 & 02 Aug & 2330 & 48.75 & 2.0 \\
\hline Transit $0.55 \mathrm{nmi}$ to Hole $1026 \mathrm{~B}$ (during pipe trip) & & & & & & \\
\hline \multicolumn{7}{|l|}{ Hole 1026B: } \\
\hline Recover CORK installed during Leg 168 & 02 Aug & 2330 & 03 Aug & 1500 & 15.50 & 0.6 \\
\hline Install CORK (includes $15.75 \mathrm{~h}$ to fish obstruction in cone) & 03 Aug & 1500 & 05 Aug & 0415 & 37.25 & 1.6 \\
\hline Deploy ROV platform & 05 Aug & 0415 & 05 Aug & 1615 & 12.00 & 0.5 \\
\hline Transit 0.55 nmi to Hole U1301B (during pipe trip) & & & & & & \\
\hline Hole U1301B: & & & & & & \\
\hline Attempt to align and cement $10^{3 / 4}$ inch casing & 05 Aug & 1615 & 06 Aug & 1700 & 24.75 & 1.0 \\
\hline Offset ship $100 \mathrm{~m}$ north-northeast $\left(19^{\circ}\right)$ of Hole U1301B & & & & & & \\
\hline Hole U1301C: & & & & & & \\
\hline APC core to $\sim 265 \mathrm{mbsf}$, conduct five temperature measurements & 06 Aug & 1700 & 08 Aug & 1545 & 46.75 & 1.9 \\
\hline Offset ship back to Hole U1301B (during pipe trip) & & & & & & \\
\hline Hole U1301B: & & & & & & \\
\hline Open hole and check depth of hole & 08 Aug & 1545 & 09 Aug & 0730 & 15.75 & 0.7 \\
\hline Hydrologic (packer) testing & 09 Aug & 0730 & 10 Aug & 2100 & 37.50 & 1.6 \\
\hline Test CORK-II casing and spring centralizers across casing gap & 10 Aug & 2100 & 11 Aug & 1315 & 16.25 & 0.7 \\
\hline Failed attempt to install CORK; $4 \frac{1}{2} 2$ casing breaks below CORK-II head & 11 Aug & 1315 & 13 Aug & 0600 & 40.75 & 1.7 \\
\hline Visually inspect failed CORK-II & 13 Aug & 0600 & 13 Aug & 1545 & 9.75 & 0.4 \\
\hline Remove (fish) failed $4 \frac{1}{2}$ inch casing from reentry cone & 13 Aug & 1545 & 14 Aug & 0600 & 14.25 & 0.6 \\
\hline Check depth of hole with drill bit & 14 Aug & 0600 & 14 Aug & 1800 & 12.00 & 0.5 \\
\hline Install CORK & 14 Aug & 1800 & 16 Aug & 1715 & 47.25 & 2.0 \\
\hline Deploy ROV platform & 16 Aug & 1715 & 17 Aug & 0415 & 11.00 & 0.5 \\
\hline Spot cement in reentry cone through ROV platform & 17 Aug & 0415 & 17 Aug & 1515 & 11.00 & 0.5 \\
\hline Remove (fish) piece of failed $4 \frac{1}{2} 2$ inch casing adjacent to reentry cone & 17 Aug & 1515 & 17 Aug & 2245 & 7.50 & 0.3 \\
\hline Conduct seafloor hazard survey surrounding Holes U1301A and U1301B & 17 Aug & 2245 & 18 Aug & 1030 & 11.75 & 0.5 \\
\hline
\end{tabular}


Table T1 (continued).

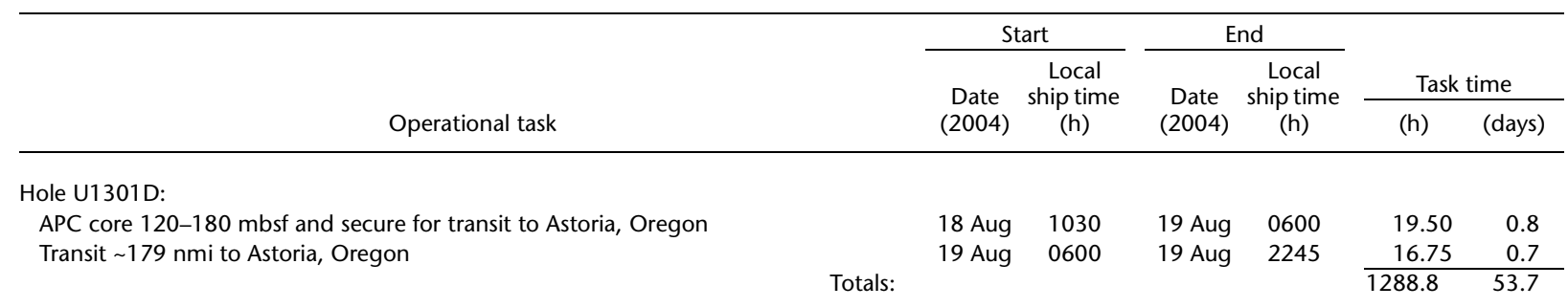

Notes: Local ship time $=$ UTC -7 . RIH $=$ run in hole, $\mathrm{POOH}=$ pull out of hole. $\mathrm{DP}=$ dynamic positioning. $\mathrm{ROV}=$ remotely operated vehicle, $\mathrm{CORK}$

$=$ Circulation Obviation Retrofit Kit, $\mathrm{RCB}=$ rotary core barrel, $\mathrm{APC}=$ advanced piston corer.

Table T2. Hole locations during Expedition 301 and related proposed site locations.

\begin{tabular}{lccll}
\hline \multicolumn{1}{c}{ Site/Hole } & Latitude & Longitude & \multicolumn{1}{c}{ Seismic line } & CDP/TR \\
\hline Hole U1301A & $47^{\circ} 45.210^{\prime} \mathrm{N}$ & $127^{\circ} 45.833^{\prime} \mathrm{W}$ & GeoB 00-466 & CDP 557 \\
Hole U1301B & $47^{\circ} 45.228^{\prime} \mathrm{N}$ & $127^{\circ} 45.827^{\prime} \mathrm{W}$ & GeoB 00-466 & CDP 556 \\
Hole U1301C & $47^{\circ} 45.280^{\prime} \mathrm{N}$ & $127^{\circ} 45.800^{\prime} \mathrm{W}$ & GeoB 00-468 & CDP 388 \\
Hole U1301D & $47^{\circ} 45.279^{\prime} \mathrm{N}$ & $127^{\circ} 45.786^{\prime} \mathrm{W}$ & GeoB 00-468 & CDP 390 \\
Hole U1026B & $47^{\circ} 45.757^{\prime} \mathrm{N}$ & $127^{\circ} 45.548^{\prime} \mathrm{W}$ & GeoB 00-203 & CDP 962 \\
Hole U1027C & $47^{\circ} 45.387^{\prime} \mathrm{N}$ & $127^{\circ} 43.867^{\prime} \mathrm{W}$ & GeoB 00-203 & CDP 741 \\
SR-2A & $47^{\circ} 45.662^{\prime} \mathrm{N}$ & $127^{\circ} 45.674^{\prime} \mathrm{W}$ & GeoB 00-482 & CDP 439 \\
FR-1A, C & $47^{\circ} 54.105^{\prime} \mathrm{N}$ & $128^{\circ} 33.468^{\prime} \mathrm{W}$ & InLine 44 (GeoB 00-365) & TR 426 \\
FR-1B & $47^{\circ} 54.132^{\prime} \mathrm{N}$ & $128^{\circ} 33.591^{\prime} \mathrm{W}$ & InLine 44 (GeoB 00-365) & TR 410 \\
DR-1A & $47^{\circ} 38.810^{\prime} \mathrm{N}$ & $127^{\circ} 26.999^{\prime} \mathrm{W}$ & EW0702 Line 1 & CDP 3070 \\
DR-2A & $47^{\circ} 37.449^{\prime} \mathrm{N}$ & $127^{\circ} 20.049^{\prime} \mathrm{W}$ & EW0702 Line 1 & CDP 1720 \\
\hline
\end{tabular}

Notes: $\mathrm{CDP}=$ common depth point, $\mathrm{TR}=$ trace within 3-D seismic grid. Hole U1301B is offset $35 \mathrm{~m}$ on a heading of $13^{\circ}$ from Hole U1301A. This offset is oblique to the strike of seismic Line GeoB00-466. The along-line distance is roughly equivalent to one shotpoint, as listed. Hole U1301C is offset $101 \mathrm{~m}$ on a heading of $19^{\circ}$ from Hole U1301B. This offset places the hole slightly south of seismic Line GeoB00-468. The closest approach is $20 \mathrm{~m}$ offset from CDP 390, as listed. Hole U1301D was positioned $18 \mathrm{~m}$ on a heading of $96^{\circ}$ from Hole U1301C. Position for Hole 1026B has been revised relative to that reported during Leg 168 . The difference $(6.6 \mathrm{~m})$ is attributed to improvements in the quality of commercially available differential Global Positioning System data during the 8 y between these expeditions. Work at Site SR-2 and Hole $1027 \mathrm{C}$ is planned for another drilling expedition to be scheduled. Sites FR-1A, FR-1B, DR-1A, and DR-2A were second-priority sites for Expedition 301 and are to be second-priority objectives for the second drilling expedition as well. 